Article

\title{
Sustainable Management Activities: A Study on the Relations between Technology Commercialization Capabilities, Sustainable Competitive Advantage, and Business Performance
}

\author{
Joon-ho Kim ${ }^{1}\left(\mathbb{D}\right.$, Bong-ihn Seok ${ }^{2}$, Hyun-ju Choi ${ }^{3}$, Seung-hye Jung ${ }^{4}$ and Jong-pil Yu ${ }^{5, *}$ \\ 1 The Cultural Policy Laboratory, Sangmyung University, Chungcheongnam-do 31066, Korea; \\ kshy4u@naver.com \\ 2 Commercialization Finance Team, Korea Institute for Advancement of Technology, Seoul 06152, Korea; \\ 1004sbi@naver.com \\ 3 Department of Cultural \& Arts Management, Sangmyung University, Chungcheongnam-do 31066, Korea; \\ hyunju_choi@naver.com \\ 4 School of Dance, Kyung Hee University, Seoul 02447, Korea; goldencats_shj@naver.com \\ 5 Department of Business Administration, Sejong University, Seoul 05006, Korea \\ * Correspondence: yujongpil@sejong.ac.kr
}

Received: 15 August 2020; Accepted: 23 September 2020; Published: 24 September 2020

check for updates

\begin{abstract}
This study investigates the effects of sustainable management activities (knowledge management activities, quality management activities, and competitive intelligence activities) on technology commercialization capabilities, sustainable competitive advantage, and business performance. In addition, it examines the effects of technology commercialization capabilities on sustainable competitive advantage and business performance as well as the effects of sustainable competitive advantage on business performance. We surveyed 409 global firms for 30 days from 1 October 2018 to 30 October 2018 and performed a structural equation model analysis on the data collected. We limited the scope of the survey to employees working at the level of team leader or above in the R\&D department. The results showed that quality management activities and competitive intelligence activities have a statistically significant positive effect on technology commercialization capabilities and quality management activities, competitive intelligence activities, and technology commercialization capabilities have a statistically significant positive effect on sustainable competitive advantage. Additionally, sustainable competitive advantage has a statistically significant positive effect on business performance.
\end{abstract}

Keywords: sustainable management activities; knowledge management activities; quality management activities; competitive intelligence activities; technology commercialization capabilities; sustainable competitive advantage; business performance; sustainability performance

\section{Introduction}

Today's business environment has undergone a transformation from labor-based to information-based industries so that only experts and technology can provide a competitive edge sustainable in the long term [1]. As society enters an age when knowledge is regarded as one of the most important assets, each organization within a company is well aware that its competitive advantage depends on its hired brainpower; thus, all organizations are investing heavily in intellectual capital [2].

A market's globalization, competition, and rapid technological advancement have a direct impact on business organizations that have to face competition both locally and internationally. According to 
Lim, Ahmed, and Zairi [3], business organizations nowadays understand that they have to regard knowledge as an asset to succeed and that it is necessary to manage knowledge effectively. In fact, a majority of companies are reframing themselves as knowledge experts [4]. These organizations view knowledge management as an innovative management tool that enables them to take advantage of attention from both academia and industry.

Several researchers [5-7] are invigorating knowledge production and sharing among organizations, thereby creating new products and services and strengthening business performance. In other words, they have proposed a new approach to performance improvement relevant to the activity competence of business organizations that realize strategic profits. They argue that organizational capabilities can strengthen customer satisfaction and loyalty, lead to better decisions, and bring enhanced labor force and performance improvements. In this sense, developed business organizations can ultimately increase their market shares and profits by effectively utilizing intellectual capital that would bring new products and services to maintain their competitiveness in a fast-changing business environment and global market [5-7].

Moreover, business organizations apply quality management with the purpose of improving process achievements. However, as previously mentioned, to accelerate improvements and attain an advantageous position in business, an organization must make it a priority to gain and integrate new knowledge [8]. It is difficult for managers to design and execute the operation of quality management and thereby gain new knowledge. In other words, knowledge can be created through a variety of channels and on various organizational levels. Therefore, it is necessary to regard knowledge management and quality management as important while seeking smooth management within a company and competitive advantage, and to execute them simultaneously [8].

Quality management has functioned as a driver for social scientists to study management philosophy and analyze methods of applying it successfully [9]. According to Flynn, Schroeder, and Sakakibara [10], the goal of quality management is to attain customer satisfaction, improve management performance, and maintain process improvement and error prevention across all levels and parts of a business organization. In other words, a concerted effort is required to realize and maintain high-quality products based on quality management and to improve and maintain business performance.

In fact, people have been paying more attention to quality management since it proved to improve the performance of business organizations. It is widely accepted that efficient management requires business execution based on quality management, which is also indispensable for attaining sustainable competitiveness [8]. It is argued that quality management can improve the performance of existing organizational processes and that companies adapting to a dynamic market condition should also regard exploration and innovation as key tasks [11,12]. However, some have suggested that company organizations should seek out competitive intelligence, including new technology and capabilities for resolving upcoming problems and capitalizing on the trends in new resources while utilizing existing resources and performing knowledge and quality management $[13,14]$.

As supported by the aforementioned discussions, the business environment has become increasingly unpredictable; thus, governments and companies are pursuing ways to determine environmental changes in their early stages to be able to react promptly [15]. To gain time for adapting to a changing environment, companies have to anticipate changes, and where they react to changes this will entail challenging consequences. This is why competitive intelligence has emerged and become an area of academia in an environment where anticipation has become difficult and competition intense [16]. Competitive intelligence helps company organizations adapt to the changing environment [13] and provide assistance so that they can navigate through difficult situations [14].

Competitive intelligence provides a framework in which integrated environmental analysis can be reflected in the decision-making processes, thereby improving them. As such, competitive intelligence has the potential to support companies in realizing their own and business targets [17]. Qiu [18] argued that companies may develop and maintain competitive advantages through competitive intelligence. Moreover, in a study on competitive intelligence, M-Brain [19] highlighted that most people responded 
that they had experienced the benefits of intelligence and had gained high profits from investment in intelligence. Competitive intelligence activities have continued to increase as measured by companies' official intelligence structures, manpower, and membership in professional competitive intelligence associations for the past 10 years. Meanwhile, it was highlighted that competitive intelligence is one of the fastest growing areas in the business world [20,21].

Furthermore, competitive intelligence is utilized as a mechanism of company organizations to transform rival companies' intelligence into outward-looking behaviors. Such organizations may take more seasoned actions compared to rival companies [22]. Moreover, given the effect of competitive intelligence on innovative performance, organizations may become more seasoned in attaining immediacy, and the utilization of explorative intelligence may invigorate business performance [23].

However, in terms of innovative capabilities, many company organizations have highlighted that it is a very important research agenda to understand how new knowledge, intelligence, and quality improvement are reflected in industrial products in a market and whether there are benefits to technological innovation [24,25]. In other words, according to existing studies, commercialization of technology functions as a key competitive factor in company organizations that are based on technology and is an indispensable and important stage for them to benefit from technological innovation [26-28]. Accordingly, commercialization of technology is recognized as a process and activity through which company organizations may benefit from technological innovation. It is also a key factor that can be structured as a value that generates wide-ranging potential income, production, and utilization [29]. Furthermore, Mitchell and Singh [30] suggested that technology commercialization can be utilized as a process for gaining ideas and a complementary knowledge tool. They defined the process of technology commercialization in the development, production, and sale of sellable products in a market.

An examination of a company's sustainable management activities can provide a foundation for sustainable competitive advantages in the future [31,32]. It has the advantage of being able to evaluate specific meanings of sustainable companies along with market changes and to examine proper organizational reactions [33]. Therefore, it is very important to categorize, observe, and interpret several factors of management activities (e.g., knowledge management, quality management, competitive intelligence, etc.). A company's sustainable management activities are relevant to several stakeholders, provide an important resource that makes one lead the competition, and ultimately improve financial performance (e.g., return on assets, return on equity, cash flow, discount cost method, etc.) [33]. In other words, they promote competitive advantages that suggest a direction to move toward so that company organizations can prepare for changes and go forward into the future that they want [31,32].

An investigation into the origin of competitive advantage has revealed considerable changes for the past several years. From the perspective of industrial structure [34], theoretical development has incorporated a variety of aspects including resource capabilities in various time zones [35,36], capabilities in innovation [28], and organizational relations [37]. The benefits of competitive advantage in inter-organizational relationships have become an important area that attracts academic interest [32]. In other words, even though a great deal of work has been done using a quantum perspective [37], the perspective of sustainable management activities has been gaining more attention as a way to understand the process to strengthen competitive advantage [32].

As previously mentioned, the strategic direction of companies' sustainable management activities (e.g., knowledge management, quality management, competitive intelligence) refers to particular approaches that companies take to produce a superior and sustainable business performance [38]. Therefore, the strategic directivity of these activities reflects the managerial perception of social environments and the framework regarding reaction to conditions [39,40]. As such, the overall strategy of sustainable management activities can be seen as an intangible resource that reflects the direction that the management team has adopted to smoothly realize the core organizational targets. Moreover, such activities will be formed as a measure to evaluate the management's internal capacity and accommodate changing market dynamics [41]. 
A management team's decision regarding the overall marking strategy may establish objectives and direction for most other organizational activities [41]. They in part entail decisions regarding the supply of tangible resources and activate areas like a mixed decision on necessary marketing, investment of marketing assets in knowledge industries, management of intellectual resources, which is the subject of recruiting (knowledge management) [42], execution techniques and activities selected in the process of business execution for organizational processes and quality control (quality management) [43], a collection of information necessary for particular types, prediction of market changes, and organization reaction (competitive intelligence) [44]. As such, through a strategic decision on sustainable management activities by a management team, all activities on an organization level apply the same method of approach [41]. If the strategy is successful, this condition can be transferred to the organization of another function. At the same time, more departmental activities will be planned and executed in addition to supporting the strategy of sustainable management activities [41].

To date, most research has focused on the relevance and connectivity of business performance based on a company's differentiation, such as overall strategic options for the management team [34], its leadership, and competitive advantage [45,46], and the research outcomes have been positive. There is evidence that overall strategy on the differentiation of management's leadership and competitive advantage is related to marketing effect (including sales) [47,48] and market orientation [49]. Moreover, there is a suggestion that the differentiation strategy for competitive advantage (local or global) and low-cost strategy correspond to the outlook that can lead to a low-cost position in a particular market condition [50]. In other words, as market share increases, the quantity of products being sold also increases and it becomes possible to attain the economies of scale that enable low-cost production. Therefore, the differentiation strategy for competitive advantage can lead to an increase in market share that is potentially sustainable and to a low-cost position [41]. However, the important question is not just regarding competitive advantage but also about deriving the capacity for sustainable management activities that would maintain a competitive advantage over time and differentiate it in a meaningful way $[41,50]$.

From this perspective, sophisticated company organizations may ultimately increase their market shares and profits by effectively utilizing knowledge management that can create new products and services to maintain their competitiveness in a rapidly changing business environment and global market [5-7]. Moreover, it may be necessary to make concerted efforts to realize and maintain high-quality products based on quality management and to improve and maintain business performance by continuously sustaining the process improvement and error prevention across all levels and parts of company organizations $[9,10]$. In addition, it is necessary to attain the potential of competitive intelligence that supports the realization of a company's own and business goals by providing a framework such that an integrated environmental analysis can be included in the decision-making processes in a company, thereby improving such processes [39]. This shows that the strategic directivity of the previously mentioned sustainable management activities is required [38]. In addition, along with a management team's perception of the social environment, it functions as a very important factor that can reflect a reaction framework $[39,40]$.

In other words, companies transform into pursuing new knowledge and information in the market, which leads to quality improvement in commercialized products and ultimately to a process or activity through technological innovation from which profits can be made $[24,25]$. This means that the strategic directivity of a company's sustainable management activities can be composed of wide-ranging potential income generation, production, and utilization values [26-30].

As previously discussed, an examination of a company's sustainable management activities can provide a foundation to build sustainable competitive advantage in the future [31,32]. Moreover, it is reported that such activities have the advantage of enabling evaluation of distinctive meanings of a company with growth potential and an examination of proper organizational response along with market changes [33]. Therefore, it is possible to learn indirectly that business achievement can be 
realized in several aspects, including resource capabilities through competitive advantage [35,36], innovative capabilities [28], and inter-organizational relationships [37].

In particular, global companies from developed countries such as the United States and the United Kingdom have steadily collected and developed materials and expertise on definitions, execution guidelines, model standards, and other practical matters concerning sustainable management activities [51,52]. At the same time, they have also made efforts to explore a larger market regarding foreign direct investment and to promote the formation of mutual investment relations with companies from other countries [53,54]. Moreover, medium-size companies and conglomerates in South Korea have also tried to apply successful cases of sustainable management activities from global companies abroad $[55,56]$. Technically speaking, it can be inferred that sustainable management activities by global companies from developed countries lead to technology commercialization and sustainable competitive advantage and ultimately have a positive impact on the value (performance achievement) of these companies [31,57-65]. In other words, sustainable management activities by global companies lead to accurate anticipation of future values and an increase of trust, ultimately creating business performance.

Nonetheless, existing studies have not been able to conduct proper empirical research that would devise such activities like knowledge management, quality management, and competitive intelligence to increase technology commercialization capabilities and to attain sustainable competitive advantage. In other words, no research has fixed the aforementioned as sustainable management activities and then examined their effect on technology commercialization capabilities and sustainable competitive advantage. Moreover, there is a lack of research on its cause-and-effect relationship with the final outcome variables, namely business performance, both financial and non-financial, from a variety of perspectives.

Furthermore, many existing studies conducted surveys with global companies and made an empirical examination. However, they have limitations in that most collected and utilized data on companies from only one country (e.g., South Korea) [66-69]. To overcome such a limitation, some studies analyzed global companies from two or more countries in Asia (e.g., China, Japan, etc.) [70,71] or Europe (e.g., the United Kingdom, Germany, etc.) [72]. However, there is also a relatively small number of such studies. Most existing studies have the limitation in that they broadly covered and conducted multifaceted surveys for global companies from Asia, Europe, North America, and Africa with the aim of generalizing their research outcomes but failed to make empirical verification.

Therefore, this study has the following research objectives. It examines the effect of sustainable knowledge management, quality management, and competitive intelligence activities by global companies from four countries (continents) including South Korea, the United States, the United Kingdom, and South Africa (all in the top 10 by worldwide GDP ranking for the past three years, except for South Africa) on technology commercialization capabilities. Moreover, it investigates the effect of three sustainable management activities on sustainable competitive advantage and business performance. It also determines the effect of technology commercialization capabilities on sustainable competitive advantage and business performance as well as the effect of sustainable competitive advantage on business performance.

In summary, this study hypothesizes that global companies' sustainable management activities can strengthen rules of competitive advantage, the decisional model for marketing, and decision support technology and lead the business environment toward a more positive direction. Moreover, the strengthened sustainable management activities may greatly help managers of the R\&D department (including marketing managers) to facilitate segmented marketing, which diversifies products, services, and sale methods per customers' preferences, thereby minimizing future uncertainty. As such, this study examines the following research questions to meet its objectives. 


\section{Research questions}

(1) What is the effect of sustainable management activities (knowledge management, quality management, competitive intelligence activities) on technology commercialization capabilities, sustainable competitive advantage, and business performance in a company?

(2) What is the effect of technology commercialization capabilities on sustainable competitive advantage and business performance in a company?

(3) What is the effect of sustainable competitive advantage on business performance in a company?

\section{Theoretical Background}

\subsection{Sustainable Management Activities}

Sustainable management activities refer to a variety of activities of accommodating economic and environmental development and opportunities derived therefrom and managing risks for companies to attain the goal of sustainability of humanity. These activities create values for shareholders in the long term [73]. In other words, these activities are companies' efforts to improve the quality of economic activities for environmental, economic, and social sustainability so that the subjects and objectives of management activities will not be limited to only the current generation but will also be sustainable to satisfy the desires of future generations. Moreover, companies use a variety of such activities to minimize risks and increase company values, including shareholder values [74].

This study focuses on the economic aspect of sustainable management activities. Economic activities refer to the tangible and intangible management activities companies perform to attain economic profits necessary for their survival. In fact, companies have to effectively utilize and allocate management resources so that profits can be created throughout the processes of all management activities, including preparation for producing products and services, production, and post-production processes. For companies to grow and develop sustainably, they must attain economic profits $[75,76]$. Furthermore, in sustainable management activities, company efforts to create profits do not only refer to efforts to grow the quantity of profits. Companies also have to make efforts to grow qualitatively in the process of profit-making. In other words, they need to make efforts to create profits as a management outcome by seeking to create new values and attain competitive advantage through technological innovation such as technology commercialization capabilities and sustainable competitive advantage while providing new product development and services to customers through R\&D investment and quality improvement [29-32].

Therefore, this study utilizes three main factors as sustainable management activities in an economic sense: knowledge management, quality management, and competitive intelligence activities. In particular, these three sustainable activities are evaluated to be those that are required to draw superior and sustainable business performance $[5-8,23,38]$. In other words, these activities can present the right direction for company management to smoothly attain the key organizational targets. Moreover, they can form the foundation for evaluating the internal capabilities of a management team and adapting to the growing market's dynamics [41]. The next section will examine the concepts of these three sustainable management activities. 


\subsection{Knowledge Management}

Knowledge management is multidimensional and is defined differently in terms of operations. For example, Chawla and Joshi [77] defined knowledge management as the process of identifying and analyzing the accessible knowledge needed to realize an organization's goals. Darroch [78] stated that knowledge management is related to knowledge acquisition, knowledge dissemination, and the usefulness of available knowledge. In addition, within a related organization's strategies and context, researchers have studied knowledge management as a process of acquisition, storing, understanding, sharing, and implementation of the measures and knowledge used in the learning process [79]. Bhatti and Qureshi [80] regarded knowledge management as an effort to seek out the intrinsic and extrinsic knowledge of individuals, groups, and organizations and to transform these resources into organizational assets that managers use to make organizational decisions. Thus, this study defines knowledge management activities as the systematic exploration of the knowledge and expertise of an organization's individual members and the sharing of that knowledge as a universal organizational resource. This includes rapidly communicating, sharing, reflecting, and applying the expertise acquired through work among organizational members and departments.

\subsection{Quality Management}

Quality management is a mainstream management method for enhancing customer satisfaction and competitive advantage by improving products, services, and business processes [81]. The origins of quality management can be traced back to statistical quality control developed by Walter Shewhart in the 1930s and popularized by William Edwards Deming and Joseph Juran in Japan in the 1950s [43]. The principles, tools, and methods of quality management returned to Western society in the 1970s and have held the attention of firms since the early 1980s [43]. Emphasis was initially placed on improving the quality of the manufacturing facilities of manufacturing companies. Subsequently, quality management spread to all organizational functions and departments across the manufacturing and service sectors [81]. Rungtusanatham, Ogden, and $\mathrm{Wu}$ [82] reported that the three factors that support the theoretical basis of quality management are based on the professional knowledge system (perception of systems, knowledge of change, knowledge theory, and psychology) researched by Deming [83], Anderson, Rungtusanatham, and Schroeder [84], and Hillmer and Karney [85,86]. The theoretical source strengthens the theoretical basis of the field of quality management [87]. Thus, as in the referenced literature, this study defines quality management activities as firm-wide, comprehensive management systems that use the participation of all members and overall methods across management activities for the long-term success of the firm. This includes performance, process, training, and employee management.

\subsection{Competitive Intelligence}

Competitive intelligence is defined as a process or practice (action) that helps executives make informed decisions and provides the firm with competitive advantages [88]. Du Toit [89] defined competitive intelligence as a strategic tool that facilitates the identification of potential opportunities and crises. Du Plessis and Gulwa [90] and Jenster and Søilen [91] also defined competitive intelligence as a strategic tool. These and other scholars consider competitive intelligence as a process that supports important decision-making. Other researchers have examined how competitive intelligence can be applied within a firm. Amara, Solberg Søilen, and Vriens [92] stated that competitive intelligence allows high-level executives, regardless of firm size, to make informed decisions on marketing, R\&D, investment tactics, and long-term business strategies. Researchers have also described competitive intelligence as a value-added concept superior to business development, market analysis, and strategic planning. Vriens and Solberg Søilen [93] noted that competitive intelligence is a necessary factor in predicting whether the firm will fall behind competitors in the industry. Thus, this study defines competitive intelligence activities as the systematic process of collecting, analyzing, and using 
information on competitor activities and the firm's business environment through systematic and rational methods. These methods include predicting the external environment, protecting information knowledge, and exercising influence.

\subsection{Technology Commercialization}

Technology commercialization refers to a firm's capability to use technology in products [94]; this is the widely accepted definition of technology commercialization. For example, Mitchell and Singh [30] defined this concept as a process of acquiring ideas, reinforcing them with complementary knowledge, developing and manufacturing products for the market and, ultimately, selling products. This perspective views the management of technology commercialization activities as vital for successful product development and sales and securing competitive advantage. Technology commercialization emphasizes the internal investments of firms that use their own resources and abilities [95-97]. Thus, technology-based firms, which are characterized by high-risk and uncertain performance, add a strategic focus to their own technology commercialization that is focused on innovative activities [98]. Additionally, technology commercialization is emphasized in the management of related firm secrets and patents and the need to introduce new products faster than competitors. These activities enable firms to discover new market opportunities and gain competitive advantages ahead of competitors [99]. Thus, it is vital for firms to efficiently commercialize their advanced technology. Accordingly, this study defines technology commercialization capabilities as all activities and processes that create added value through the transfer, exchange, diffusion, and application of the developed technology. This includes the speed of commercialization, market scope, and technological breadth of the product (good).

\subsection{Sustainable Competitive Advantage}

Competitive advantage refers to the degree to which an organization can obtain a favorable position compared to its competitors [100]. Thus, competitive advantage, which is the product of management decisions, is composed of a variety of factors related to capabilities that enable a business organization to differentiate itself from competitors [101]. Previous literature has classified competitive advantage as competitive capabilities in terms of price/cost, quality, delivery, and others through consistent and flexible methods [101]. In another study on competitive advantage, Koufteros, Vonderembse, and Doll [102] described a research framework of competitive capabilities and defined it using five dimensions: (1) competitive pricing, (2) premium pricing, (3) customer-oriented value, (4) delivery reliability, and (5) production innovation. These dimensions were described by Tracey, Vonderembse, and Lim [101] and Li et al. [103]. Together, the dimensions of competitive advantage include price/cost, delivery reliability, production innovation, and marketization timing. Thus, this study defines sustainable competitive advantage as the process of securing an advantageous position compared to competitors by providing superior service value while improving convenience facilities, lowering costs, or justifying high prices. This value includes providing a high level of service to customers regardless of price, implementing a service model superior to competitors, supplying products or services that exceed the quality of current levels, and investing in marketing activities to a greater extent than competitors. 


\subsection{Business Performance}

The measurement of business performance is based on financial performance indicators such as net profit margin, sales, market share, and return on investment (ROI) [104]. Powell [105] noted that there have been many attempts to measure business performance through the subjective survey evaluations of business organization members rather than through financial performance. Furthermore, financial performance has many limitations in that it measures business performance after the fact and cannot accurately reflect a firm's intangible value. Therefore, composite indicators that include nonfinancial performance data rather than single indicators based on financial performance are preferable [104,105]. Typically, as nonfinancial performance is subjective performance, the scope of measurement is broad and inappropriate as an indicator of short-term business performance. However, as nonfinancial performance is measured using long-term and diverse criteria, it can address the problems of financial performance [106]. Hence, the financial performance indicators used to measure a firm's short-term performance are typically expressed in terms of profitability. In addition, profitability is the most important and key criterion for evaluating the final business performance of a firm $[107,108]$. Thus, this study defines business performance as the degree of performance (numerical data) contributed by individuals, departments, and the entire organization. This includes both financial and nonfinancial performance.

\section{Research Method}

\subsection{Research Model}

This study investigates the effects of sustainable management activities (knowledge management activities, quality management activities, and competitive intelligence activities) on technology commercialization capabilities, sustainable competitive advantage, and business performance. Figure 1 shows the research model.

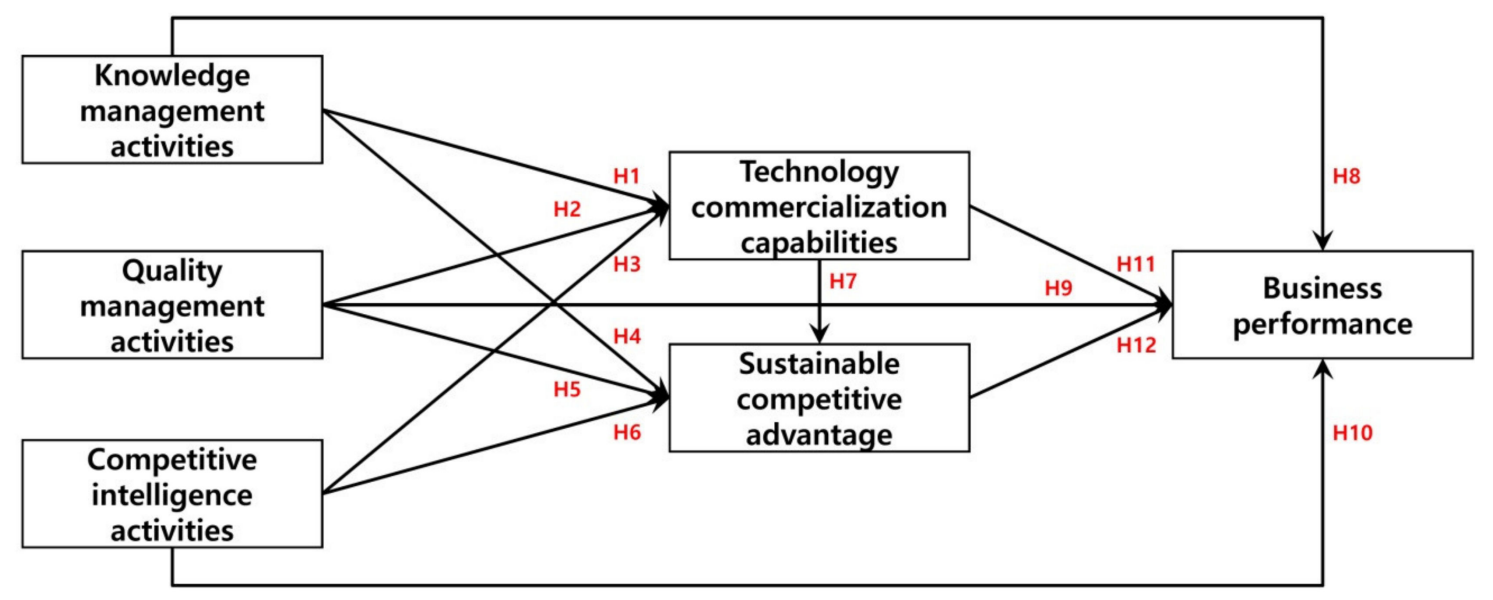

Figure 1. Research model.

\subsection{Research Hypotheses}

\subsubsection{Knowledge Management Activities and Technology Commercialization Capabilities}

The foundation of a firm's internal knowledge management is the data used to acquire new technologies and create products (goods); abundant data can strengthen future commercialization capabilities. Thus, a firm's existing knowledge management base seeks out knowledge, processes and absorbs that knowledge, and improves the firm's ability to generate new technical knowledge for problem-solving [109]. Additionally, knowledge management-based R\&D helps a firm's leadership choose the correct path among numerous uncertain and unfamiliar options [64]. As the firm's technical knowledge expands, management can better understand the constraints or weaknesses of various 
internal R\&D directions, thus increasing the efficiency of the decision-making process. Therefore, firms with in-depth knowledge of a particular field can perform more efficient R\&D processes that create innovation [110]. As a result, efficient R\&D based on knowledge management leads to the development of new products (goods), the improvement of more suitable products (goods), and the acquisition of more creative technologies and integration capabilities [110]. Therefore, based on the previous literature, we set the following research hypothesis:

Hypothesis 1 (H1). Knowledge management activities have a positive (+) effect on technology commercialization capabilities.

\subsubsection{Quality Management Activities and Technology Commercialization Capabilities}

Increasing quality-oriented activities can soon form and spread a culture of quality within a firm [111]. Furthermore, if a culture of quality forms and spreads within a firm, the firm will increase its efforts to more systematically pursue quality management [112]. That is, by continuously supplying quality products (goods) in a timely manner through continuous quality improvement activities, the firm can ultimately establish customers' trust [113]. These quality-oriented activities lead to the continuous improvement of products (goods) and technological development. Moreover, firms perform scientific quality improvement activities to eventually improve process capabilities [62]. In turn, improved process capabilities encourage the development of creative technology, which can generate future value for the firm [62]. Therefore, based on the previous literature we set the following research hypothesis:

Hypothesis 2 (H2). Quality management activities have a positive (+) effect on technology commercialization capabilities.

\subsubsection{Competitive Intelligence Activities and Technology Commercialization Capabilities}

Today, firms face a dynamic environment resulting from globalization, informatization, and technological innovation [114]. In this dynamic environment, firms seize new opportunities and face new threats as they focus on competitive intelligence [115]. In other words, firms seek to create new knowledge and skills by understanding and adapting to this dynamic environment [116]. Specifically, while expanding their understanding of new changes in the environment through competitive intelligence activities, firms further enhance technology commercialization through continuous idea development and new product development $[57,117]$. Therefore, competitive intelligence activities accelerate progressive technological commercialization and break down difficult situations, ultimately leading to environmental changes $[57,117]$. Therefore, based on the previous literature, we set the following research hypothesis:

Hypothesis 3 (H3). Competitive intelligence activities have a positive (+) effect on technology commercialization capabilities.

\subsubsection{Knowledge Management Activities and Sustainable Competitive Advantage}

Scholars consider difficult-to-imitate knowledge resources developed within an organization a major source of competitive advantage $[28,118]$. Thus, knowledge management firms can create sustainable competitive advantage [119]. Knowledge management does not involve competition with other firms but, rather, the creation of competitive advantages from the firm's knowledge resources [63]. In addition, as explained in resource-based theories such as social complexity and causal ambiguity, inimitable factors further enhance a firm's competitive advantage [120]. As mentioned earlier, from the resource-based perspective that a firm's sustainable competitive advantage stems from its own knowledge resources, it is crucial to properly manage the firm's business resources on global networks [121]. Accordingly, knowledge is an important resource for firms. As the recognition of 
knowledge as a source of competitive advantage spreads, sharing and diffusing knowledge resources enable firms to secure other competitive advantages [122,123]. Therefore, based on the previous literature, we set the following research hypothesis:

Hypothesis 4 (H4). Knowledge management activities have a positive $(+)$ effect on sustainable competitive advantage.

\subsubsection{Quality Management Activities and Sustainable Competitive Advantage}

Quality management impacts an organization's overall performance and an organization's competitive advantage. An organization's competitive advantage improves through price/cost, delivery reliability, market orientation, and product innovation [31]. Previous research indicated that various elements of quality management influence competitive advantage. As a simple example, the empirical research of Powell [124] showed that quality management can strengthen competitive advantage. Oakland [125] defined quality management as a method to improve competitiveness that can also promote an organization's flexibility. Moreover, Naveh and Marcus [126] reported that the proper implementation of ISO 9000 standards can lead to competitive advantages with ISO 9000 certification. In fact, since quality management is used in firms' everyday activities and as a catalyst for change, it can lead to competitive advantages in management and operations [31]. Therefore, based on the previous literature, we set the following research hypothesis:

Hypothesis 5 (H5). Quality management activities have a positive (+) effect on sustainable competitive advantage.

\subsubsection{Competitive Intelligence Activities and Sustainable Competitive Advantage}

Information from inside and outside the firm and from a social competitive environment is collected ethically and legally, processed, and analyzed, producing new competitive information [127,128]. This competitive information plays an integral role in promoting competitive advantage [127,128]. Competitive intelligence helps executives understand changes in the market and industry and anticipate potential risks [129]. Thus, competitive intelligence allows firms regardless of size to make informed decisions concerning marketing, $R \& D$, investment tactics, and long-term business strategies [92]. Competitive intelligence creates added value and is superior to new business development, market exploration, and strategic planning [130]. Previous literature noted that competitive intelligence affects important decisions throughout the entire firm environment and is a key factor in securing and implementing competitive advantages [58]. Therefore, based on the previous literature, we set the following research hypothesis:

Hypothesis 6 (H6). Competitive intelligence activities have a positive $(+)$ effect on sustainable competitive advantage. 


\subsubsection{Technology Commercialization Capabilities and Sustainable Competitive Advantage}

In a rapidly changing market environment, a firm's technology commercialization is a key success factor for survival [131]. That is, a firm must secure competitive advantages to survive in a rapidly changing market environment $[61,132]$. Firms use technology commercialization to enhance customer satisfaction by developing products (goods) that meet customer preferences and demands [133]. Companies achieve high levels of customer satisfaction by providing what the customer wants and needs. In an age of infinite competition, the key to competitive advantage is determining what customers want before competitors do. Thus, the key is to satisfy customers' desires [134].

Technology commercialization is considered a vital asset in securing and maintaining competitive advantage [131]. Moreover, technology commercialization that can help ensure that appropriate technology is available on the market and can be quickly developed and launched will increase a firm's competitiveness and its products' life cycles [61,132]. Supporting this argument, Chen [135] stated that the technology commercialization capabilities of new venture firms have a positive effect on business performance. Moreover, Hwang and Sung [136] suggested that an export firm's technology commercialization capabilities act as a major catalyst for enhancing competitive advantage. Therefore, based on the previous literature, we set the following research hypothesis:

Hypothesis 7 (H7). Technology commercialization capabilities have a positive (+) effect on sustainable competitive advantage.

\subsubsection{Knowledge Management Activities and Business Performance}

Barney [137] stated that a firm can increase its business performance by properly implementing knowledge management. Thus, knowledge management activities such as knowledge acquisition, creation, sharing, and transfer play an important role in improving management performance $[138,139]$. These scholars emphasized that firms seeking to increase their competitiveness must expand their investment in management activities to increase revenue, sales, and market share. Additionally, Seba and Rowley [65] and Zack, McKeen, and Singh [140] reported that knowledge management activities enhance the capabilities of business organization members and ultimately improve business performance. Therefore, based on the previous literature, we set the following research hypothesis:

Hypothesis 8 (H8). Knowledge management activities have a positive (+) effect on business performance.

\subsubsection{Quality Management Activities and Business Performance}

Scholars have already found that quality management directly affects firms' business performance. That is, quality management can increase a firm's market share [141-144], customer satisfaction [145-147], and financial performance [141,148-152]. As a result, firms can improve sales, return on assets (ROA), and market share [153] by investing in quality management. Therefore, based on the previous literature, we set the following research hypothesis:

Hypothesis 9 (H9). Quality management activities have a positive (+) effect on business performance. 


\subsubsection{Competitive Intelligence Activities and Business Performance}

Firms survive through interactions with the external environment [154]. Furthermore, business performance can only be improved if the firm is linked to the external environment through business strategies [34]. Thus, a firm possessing clear insight and understanding of its external environment can effectively make decisions and establish strategies, thereby achieving a high level of competitive advantage [155] and rapidly improving business performance [60]. A firm must support insight and understanding of the external environment to successfully operate, and these factors can be secured through competitive intelligence activities [156,157]. A firm can perform competitive intelligence activities to make effective decisions and establish strategies positively impacting business performance. Therefore, based on the previous literature, we set the following research hypothesis:

Hypothesis 10 (H10). Competitive intelligence activities have a positive $(+)$ effect on business performance.

\subsubsection{Technology Commercialization Capabilities and Business Performance}

In technology-based firms, technology commercialization is composed of new product development strategies and market success $[25,158]$. Thus, by introducing new technologies, firms can effectively respond to customer needs and changes in the environment. Through successful technology commercialization, firms can realize potential customer demand in terms of cost, speed, quality, and the newest technological attributes [97]. Previous studies report that firms improve product quality through technology commercialization capabilities and apply them to new technology and market trends. In addition, research suggests that technology commercialization can lead to competitive advantages and improved business performance [131,135,159-161]. From this perspective, the results of new technology commercialization activities vary widely depending on the scale of commercialization and the manner in which it is implemented [162,163]. Thus, in today's rapidly changing business environment, successful technology commercialization improves business performance and strengthens firm growth and competitiveness. Therefore, based on the previous literature, we set the following research hypothesis:

Hypothesis 11 (H11). Technology commercialization capabilities have a positive $(+)$ effect on business performance.

\subsubsection{Sustainable Competitive Advantage and Business Performance}

Possessing a competitive advantage implies that a firm provides at least one of either lower prices, higher quality, better reliability, or faster delivery compared to competitors. These capabilities increase the overall performance of the organization [164]. Competitive advantages can increase business performance, customer satisfaction and loyalty, and relationship efficiency. Thus, brands with high customer loyalty experience less competition in their target areas, thereby increasing sales and profitability [165]. Furthermore, organizations that offer high-quality products can switch to a premium pricing model and increase profit margins and ROI. Organizations with short time-to-market and rapid product innovation are emerging as market leaders improving both their market share and sales [103]. Therefore, based on the previous literature, we set the following research hypothesis:

Hypothesis 12 (H12). Sustainable competitive advantage has a positive (+) effect on business performance. 


\subsection{Survey Subjects and Data Collection}

We conducted the survey for a total of 30 days from 1 October 2018 to 30 October 2018. The surveys were collected through Entrust Survey (http://entrustsurvey.com), a global survey sampling company. The surveys were provided in Korean and English. We surveyed a total of 409 global firms across Asia, Europe, North America, and Africa: 159 in Korea, 100 in the United States, 100 in the United Kingdom, and 50 companies in South Africa. We limited the scope of the survey to employees working at the level of team leader (or executive) or above in the R\&D department. In particular, the reason why the number of samples of American, British, and South African companies collected by this global research firm was smaller than that of South Korean companies is as follows. As previously mentioned, the research subjects were employees with a rank of or above team leader (or executive board member) who worked in the R\&D department in companies of middle or above standing. Therefore, this study utilized the maximum number of companies from which qualifying surveys can be collected. Table 1 summarizes the collected characteristics of the firms and respondents.

Table 1. General characteristics of the sample $(\mathrm{N}=409)$.

\begin{tabular}{|c|c|c|c|c|c|c|c|}
\hline \multicolumn{4}{|c|}{ Firm Characteristics } & \multicolumn{4}{|c|}{ Respondent Characteristics } \\
\hline $\begin{array}{l}\text { Firm } \\
\text { size }\end{array}$ & Large enterprise & 193 & 47.2 & $\begin{array}{l}\text { Respondent } \\
\text { gender }\end{array}$ & Male & 272 & 66.5 \\
\hline \multirow{8}{*}{$\begin{array}{l}\text { Firm } \\
\text { sector }\end{array}$} & Services & 22 & 5.4 & \multirow{3}{*}{$\begin{array}{l}\text { Respondent } \\
\text { age }\end{array}$} & $20 \mathrm{~s}$ & 76 & 18.6 \\
\hline & Finance & 25 & 6.1 & & $30 \mathrm{~s}$ & 190 & 46.5 \\
\hline & Manufacturing & 169 & 41.3 & & $40 \mathrm{~s}$ & 114 & 27.9 \\
\hline & Medicine/Pharmaceuticals & 41 & 10 & \multirow{4}{*}{$\begin{array}{l}\text { Respondent } \\
\text { position }\end{array}$} & Team leader & 125 & 30.6 \\
\hline & Sales/Distribution & 28 & 6.8 & & General manager & 118 & 28.9 \\
\hline & IT/Web/Communications & 58 & 14.2 & & Head manager & 35 & 8.6 \\
\hline & Media/Design & 11 & 2.7 & & Other (executives, etc.) & 131 & 32 \\
\hline & Other & 8 & 2 & \multirow{2}{*}{$\begin{array}{l}\text { Respondent } \\
\text { education }\end{array}$} & High school graduate & 17 & 4.2 \\
\hline $\begin{array}{l}\text { Firm } \\
\text { location }\end{array}$ & South Africa & 50 & 12.2 & & Other & 2 & 0.5 \\
\hline \multirow{7}{*}{$\begin{array}{l}\text { Firm } \\
\text { establishment } \\
\text { period }\end{array}$} & $1-5$ years & 21 & 5.1 & \multirow{7}{*}{$\begin{array}{l}\text { Respondent } \\
\text { tenure } \\
\text { (current } \\
\text { employer) }\end{array}$} & Less than 1 year & 6 & 1.5 \\
\hline & $6-10$ years & 62 & 15.2 & & $1-5$ years & 121 & 29.6 \\
\hline & $11-15$ years & 70 & 17.1 & & $6-10$ years & 151 & 36.9 \\
\hline & $16-20$ years & 60 & 14.7 & & $11-15$ years & 67 & 16.4 \\
\hline & $21-25$ years & 48 & 11.7 & & $16-20$ years & 41 & 10 \\
\hline & 26-30 years & 33 & 8.1 & & 21-25 years & 13 & 3.2 \\
\hline & 30 years or more & 115 & 28.1 & & 25 years or more & 10 & 2.5 \\
\hline
\end{tabular}

\subsection{Variable Measurements}

Table 2 shows the operational definitions and measurements of the variables used in this study. We prepared the questionnaire items for all the variables with reference to the previous studies listed in the table while modifying and supplementing them according to the purpose of this study. In addition, we developed some of the items ourselves. 
Table 2. Operational definitions and measurements of variables.

\begin{tabular}{|c|c|c|}
\hline Variable & Operational Definition & Measurement Item \\
\hline \multirow{7}{*}{$\begin{array}{l}\text { Knowledge } \\
\text { management } \\
\text { activities }\end{array}$} & \multirow{7}{*}{$\begin{array}{l}\text { Institutionalization of active creation and sharing } \\
\text { of knowledge within business organizations }\end{array}$} & $\begin{array}{l}\text { 1. Promotion of learning activities among organization } \\
\text { members }\end{array}$ \\
\hline & & $\begin{array}{l}\text { 2. Rapid communication of information on executive } \\
\text { decisions to departments }\end{array}$ \\
\hline & & $\begin{array}{l}\text { 3. Contribution to the overall performance of the firm by } \\
\text { sharing specific knowledge with organization members }\end{array}$ \\
\hline & & $\begin{array}{l}\text { 4. Reflection of information and knowledge on market } \\
\text { trends and new products }\end{array}$ \\
\hline & & $\begin{array}{l}\text { 5. Cooperation with related departments when } \\
\text { promoting work }\end{array}$ \\
\hline & & $\begin{array}{l}\text { 6. Quick reflection of information on executive decisions } \\
\text { at work }\end{array}$ \\
\hline & & 7. Application of best practices at work \\
\hline \multicolumn{3}{|c|}{$\begin{array}{l}\text { Source: Seok, Han, and Kim [166] } \\
\text { Scale: } 11-\text { point Likert scale (0 points: Very low-10 points: Extremely good) }\end{array}$} \\
\hline \multirow{8}{*}{$\begin{array}{l}\text { Quality } \\
\text { management } \\
\text { activities }\end{array}$} & \multirow{8}{*}{$\begin{array}{l}\text { Continuous activities to improve the level of } \\
\text { quality of the firm's goods }\end{array}$} & $\begin{array}{l}\text { 1. Development and management of performance } \\
\text { measurement indicators for internal operations }\end{array}$ \\
\hline & & $\begin{array}{l}\text { 2. Appropriate management through analysis of work } \\
\text { performance }\end{array}$ \\
\hline & & $\begin{array}{l}\text { 3. Active implementation of work improvement to } \\
\text { increase performance }\end{array}$ \\
\hline & & $\begin{array}{l}\text { 4. Active implementation of work process improvement } \\
\text { to increase work efficiency }\end{array}$ \\
\hline & & $\begin{array}{l}\text { 5. Operation of various programs for employee career } \\
\text { development }\end{array}$ \\
\hline & & 6. Employees' level of interest in work training \\
\hline & & 7. Collection and application of employees' opinions \\
\hline & & $\begin{array}{l}\text { 8. Regular measurement of employee satisfaction and } \\
\text { reflection in work improvement }\end{array}$ \\
\hline \multicolumn{3}{|c|}{$\begin{array}{l}\text { Source: Seok, Han, and Kim [166] } \\
\text { Scale: } 11 \text {-point Likert scale (0 points: Very low-10 points: Extremely good) }\end{array}$} \\
\hline \multirow{10}{*}{$\begin{array}{l}\text { Competitive } \\
\text { intelligence } \\
\text { activities }\end{array}$} & \multirow{10}{*}{$\begin{array}{l}\text { Systematic process of collecting, analyzing, and } \\
\text { using information on competitors' activities and } \\
\text { the firm's business environment }\end{array}$} & 1. Specific understanding of supplier trends \\
\hline & & 2. Specific understanding of competitor firm activities \\
\hline & & 3. Specific understanding of buyer trends \\
\hline & & $\begin{array}{l}\text { 4. Specific understanding of trends in technological } \\
\text { innovation }\end{array}$ \\
\hline & & $\begin{array}{l}\text { 5. Extent of employee pledges regarding information } \\
\text { security }\end{array}$ \\
\hline & & 6. Thoroughness of computer system security \\
\hline & & 7. Emphasis on the importance of information security \\
\hline & & $\begin{array}{l}\text { 8. Help provided by competitive intelligence activities to } \\
\text { maintain friendly relationships with suppliers }\end{array}$ \\
\hline & & $\begin{array}{l}\text { 9. Help provided by competitive intelligence activities to } \\
\text { effectively exercise influence over competitors }\end{array}$ \\
\hline & & $\begin{array}{l}\text { 10. Help provided by competitive intelligence activities } \\
\text { to maintain friendly relationships with social pressure } \\
\text { groups }\end{array}$ \\
\hline \multicolumn{3}{|c|}{$\begin{array}{l}\text { Source: Kim, John, and Ravi [167] } \\
\text { Scale: } 11-\text { point Likert scale (0 points: Very low-10 points: Extremely good) }\end{array}$} \\
\hline
\end{tabular}


Table 2. Cont.

\begin{tabular}{|c|c|c|}
\hline Variable & Operational Definition & Measurement Item \\
\hline \multirow{11}{*}{$\begin{array}{l}\text { Technology } \\
\text { commercialization } \\
\text { capabilities }\end{array}$} & \multirow{11}{*}{$\begin{array}{l}\text { Various activities and processes that create added } \\
\text { value through the transfer, exchange, diffusion, } \\
\text { and application of developed technologies }\end{array}$} & 1. Ability to implement product ideas in a timely manner \\
\hline & & 2. Ability to develop products in a timely manner \\
\hline & & $\begin{array}{l}\text { 3. Ability to introduce products to the market in a timely } \\
\text { manner }\end{array}$ \\
\hline & & $\begin{array}{l}\text { 4. Ability to improve products tailored to } \\
\text { demographically different markets }\end{array}$ \\
\hline & & $\begin{array}{l}\text { 5. Ability to create new products tailored to } \\
\text { demographically different markets }\end{array}$ \\
\hline & & $\begin{array}{l}\text { 6. Ability to improve products tailored to regionally } \\
\text { different markets }\end{array}$ \\
\hline & & $\begin{array}{l}\text { 7. Ability to create new products tailored to regionally } \\
\text { different markets }\end{array}$ \\
\hline & & $\begin{array}{l}\text { 8. Ability to acquire technology to improve existing } \\
\text { products }\end{array}$ \\
\hline & & $\begin{array}{l}\text { 9. Ability to integrate technology to improve existing } \\
\text { products }\end{array}$ \\
\hline & & 10. Ability to acquire technology to create new products \\
\hline & & 11. Ability to integrate technology to create new products \\
\hline \multicolumn{3}{|c|}{$\begin{array}{l}\text { Source: Seok, Han, and Kim [166] } \\
\text { Scale: } 11 \text {-point Likert scale (0 points: Very low-10 points: Extremely good) }\end{array}$} \\
\hline \multirow{8}{*}{$\begin{array}{l}\text { Sustainable } \\
\text { competitive } \\
\text { advantage }\end{array}$} & \multirow{8}{*}{$\begin{array}{l}\text { Securing competitive advantages while } \\
\text { determining whether the firm can maintain a lead } \\
\text { on competitors }\end{array}$} & $\begin{array}{l}\text { 1. Prioritization of high levels of service for customers } \\
\text { regardless of price }\end{array}$ \\
\hline & & 2. Securing of technology superior to competitors \\
\hline & & 3. Securing of service model superior to competitors \\
\hline & & $\begin{array}{l}\text { 4. Supplying products at least one level higher than the } \\
\text { current level }\end{array}$ \\
\hline & & $\begin{array}{l}\text { 5. Supplying services at least one level higher than the } \\
\text { current level }\end{array}$ \\
\hline & & $\begin{array}{l}\text { 6. More investments in marketing activities (advertising) } \\
\text { than competitors }\end{array}$ \\
\hline & & $\begin{array}{l}\text { 7. More investments in marketing activities (promotion) } \\
\text { than competitors }\end{array}$ \\
\hline & & 8. Focus on brand awareness of products or services \\
\hline \multicolumn{3}{|c|}{$\begin{array}{l}\text { Source: Lee and Park [168] } \\
\text { Scale: } 11 \text {-point Likert scale ( } 0 \text { points: Very low-10 points: Extremely good) }\end{array}$} \\
\hline \multirow{8}{*}{$\begin{array}{l}\text { Business } \\
\text { performance }\end{array}$} & \multirow{8}{*}{$\begin{array}{c}\text { Performance contributed to } \\
\text { individuals/departments/the entire organization } \\
\text { within a firm }\end{array}$} & $\begin{array}{l}\text { 1. Achievement of internal management goals in market } \\
\text { structure in the last three years (2015-2017) }\end{array}$ \\
\hline & & $\begin{array}{l}\text { 2. Achievement of internal cost reduction goals in } \\
\text { market structure in the last three years (2015-2017) }\end{array}$ \\
\hline & & $\begin{array}{l}\text { 3. Implementation of internal business innovation } \\
\text { programs in market structure in the last three years } \\
\qquad(2015-2017)\end{array}$ \\
\hline & & $\begin{array}{l}\text { 4. Improvement of internal competitiveness in the } \\
\text { market in the last three years (2015-2017) }\end{array}$ \\
\hline & & 5. Sales achieved in the last three years (2015-2017) \\
\hline & & 6. Sales profit in the last three years (2015-2017) \\
\hline & & $\begin{array}{l}\text { 7. Operating profit achieved in the last three years } \\
\qquad(2015-2017)\end{array}$ \\
\hline & & 8. Net profit achieved in the last three years (2015-2017) \\
\hline \multicolumn{3}{|c|}{$\begin{array}{l}\text { Source: Kim and Jung [169], Han, Seok, and Kim [170] } \\
\text { Scale: } 11 \text {-point Likert scale (0 points: Extremely low-10 points: Extremely high) }\end{array}$} \\
\hline
\end{tabular}

\section{Empirical Analysis}

\subsection{Reliability and Validity}

We used the Cronbach's alpha coefficient for the reliability analysis of this study and conducted factor analysis through orthogonal factor rotation (Varimax) using the exploratory factor analysis 
method. Tables 3 and 4 summarize the analysis results of all variables composed of knowledge management, quality management, competitive intelligence, technology commercialization capabilities, sustainable competitive advantage, and business performance. Based on the analysis, the alpha coefficient of all variables showed a minimum of 0.939 and a maximum of 0.971 , indicating high reliability. Moreover, the loading of each factor ranged from 0.528 to 0.840 , verifying the validity.

Table 3. Reliability and exploratory factor analysis (independent variables).

\begin{tabular}{|c|c|c|c|c|c|}
\hline Variable & Measurement Item & Factor Loading & Eigenvalue & Variance $(\%)$ & $\begin{array}{l}\text { Reliability } \\
\qquad(\alpha)\end{array}$ \\
\hline \multirow{7}{*}{$\begin{array}{c}\text { Knowledge } \\
\text { management activities }\end{array}$} & Knowledge management 1 & 0.753 & \multirow{7}{*}{5.637} & \multirow{7}{*}{22.547} & \multirow{7}{*}{0.939} \\
\hline & Knowledge management 2 & 0.653 & & & \\
\hline & Knowledge management 3 & 0.778 & & & \\
\hline & Knowledge management 4 & 0.66 & & & \\
\hline & Knowledge management 5 & 0.714 & & & \\
\hline & Knowledge management 6 & 0.528 & & & \\
\hline & Knowledge management 7 & 0.689 & & & \\
\hline \multirow{8}{*}{$\begin{array}{l}\text { Quality management } \\
\text { activities }\end{array}$} & Quality management 1 & 0.718 & \multirow{8}{*}{9.063} & \multirow{8}{*}{36.252} & \multirow{8}{*}{0.956} \\
\hline & Quality management 2 & 0.736 & & & \\
\hline & Quality management 3 & 0.759 & & & \\
\hline & Quality management 4 & 0.723 & & & \\
\hline & Quality management 5 & 0.76 & & & \\
\hline & Quality management 6 & 0.761 & & & \\
\hline & Quality management 7 & 0.75 & & & \\
\hline & Quality management 8 & 0.724 & & & \\
\hline \multirow{10}{*}{$\begin{array}{c}\text { Competitive } \\
\text { intelligence activities }\end{array}$} & Competitive intelligence 1 & 0.756 & \multirow{10}{*}{3.552} & \multirow{10}{*}{14.207} & \multirow{10}{*}{0.939} \\
\hline & Competitive intelligence 2 & 0.711 & & & \\
\hline & Competitive intelligence 3 & 0.739 & & & \\
\hline & Competitive intelligence 4 & 0.665 & & & \\
\hline & Competitive intelligence 5 & 0.666 & & & \\
\hline & Competitive intelligence 6 & 0.792 & & & \\
\hline & Competitive intelligence 7 & 0.8 & & & \\
\hline & Competitive intelligence 8 & 0.582 & & & \\
\hline & Competitive intelligence 9 & 0.663 & & & \\
\hline & Competitive intelligence 10 & 0.649 & & & \\
\hline
\end{tabular}

Table 4. Reliability and exploratory factor analysis (parameters and dependent variables).

\begin{tabular}{|c|c|c|c|c|c|}
\hline Variable & Measurement Item & Factor Load & Eigenvalue & Variance $(\%)$ & Reliability $(\alpha)$ \\
\hline \multirow{11}{*}{$\begin{array}{l}\text { Technology } \\
\text { commercialization } \\
\text { capabilities }\end{array}$} & Technology commercialization 1 & 0.781 & \multirow{11}{*}{8.547} & \multirow{11}{*}{31.656} & \multirow{11}{*}{0.971} \\
\hline & Technology commercialization 2 & 0.746 & & & \\
\hline & Technology commercialization 3 & 0.774 & & & \\
\hline & Technology commercialization 4 & 0.774 & & & \\
\hline & Technology commercialization 5 & 0.785 & & & \\
\hline & Technology commercialization 6 & 0.716 & & & \\
\hline & Technology commercialization 7 & 0.740 & & & \\
\hline & Technology commercialization 8 & 0.774 & & & \\
\hline & Technology commercialization 9 & 0.745 & & & \\
\hline & Technology commercialization 10 & 0.733 & & & \\
\hline & Technology commercialization 11 & 0.771 & & & \\
\hline \multirow{8}{*}{$\begin{array}{l}\text { Sustainable } \\
\text { competitive } \\
\text { advantage }\end{array}$} & Competitive advantage 1 & 0.646 & \multirow{8}{*}{5.567} & \multirow{8}{*}{20.620} & \multirow{8}{*}{0.945} \\
\hline & Competitive advantage 2 & 0.602 & & & \\
\hline & Competitive advantage 3 & 0.687 & & & \\
\hline & Competitive advantage 4 & 0.628 & & & \\
\hline & Competitive advantage 5 & 0.661 & & & \\
\hline & Competitive advantage 6 & 0.716 & & & \\
\hline & Competitive advantage 7 & 0.721 & & & \\
\hline & Competitive advantage 8 & 0.658 & & & \\
\hline \multirow{8}{*}{$\begin{array}{l}\text { Business } \\
\text { performance }\end{array}$} & Business performance 1 & 0.739 & \multirow{8}{*}{6.490} & \multirow{8}{*}{24.038} & \multirow{8}{*}{0.956} \\
\hline & Business performance 2 & 0.689 & & & \\
\hline & Business performance 3 & 0.607 & & & \\
\hline & Business performance 4 & 0.652 & & & \\
\hline & Business performance 5 & 0.820 & & & \\
\hline & Business performance 6 & 0.819 & & & \\
\hline & Business performance 7 & 0.826 & & & \\
\hline & Business performance 8 & 0.840 & & & \\
\hline
\end{tabular}

\subsection{Confirmatory Factor Analysis}

We conducted confirmatory factor analysis on all variables including knowledge management, quality management, competitive intelligence, technology commercialization capabilities, sustainable competitive advantage, and business performance. Table 5 shows the 'confirmatory factor analysis' 
used in this study. According to the results, the factor loading (standardization coefficient) was 0.5 or more, and the composite construct reliability (CCR) was 0.7 or more. The fit index was confirmed to be $\chi^{2}=3384.072\left(\mathrm{df}=1240, \chi^{2} / \mathrm{df}=2.729, p\right.$-value $\left.=0.000\right)$, Normed Fit Index $(\mathrm{NFI})=0.868$, Comparative Fit Index $(\mathrm{CFI})=0.912$, and Root Mean Square Error of Approximation $($ RMSEA $)=0.065$. Therefore, the statistical values of all measurement models were considered appropriate for the structural equation model analysis [171].

Table 5. Confirmatory factor analysis.

\begin{tabular}{|c|c|c|c|c|c|}
\hline Variable & Measurement Item & Standardization Factor & S.E. & C.R. & CCR \\
\hline \multirow{7}{*}{$\begin{array}{l}\text { Knowledge } \\
\text { management } \\
\text { activities }\end{array}$} & Knowledge management 1 & 0.825 & 0.051 & 19.667 & \multirow{7}{*}{0.778} \\
\hline & Knowledge management 2 & 0.808 & 0.041 & 25.893 & \\
\hline & Knowledge management 3 & 0.865 & 0.047 & 20.339 & \\
\hline & Knowledge management 4 & 0.825 & 0.050 & 19.187 & \\
\hline & Knowledge management 5 & 0.794 & 0.047 & 19.349 & \\
\hline & Knowledge management 6 & 0.799 & 0.046 & 21.822 & \\
\hline & Knowledge management 7 & 0.863 & - & Fixed & \\
\hline \multirow{8}{*}{$\begin{array}{c}\text { Quality } \\
\text { management } \\
\text { activities }\end{array}$} & Quality management 1 & 0.826 & 0.037 & 21.513 & \multirow{8}{*}{0.841} \\
\hline & Quality management 2 & 0.856 & 0.037 & 22.932 & \\
\hline & Quality management 3 & 0.866 & 0.037 & 23.411 & \\
\hline & Quality management 4 & 0.860 & 0.035 & 23.136 & \\
\hline & Quality management 5 & 0.854 & 0.042 & 22.817 & \\
\hline & Quality management 6 & 0.859 & 0.042 & 23.047 & \\
\hline & Quality management 7 & 0.860 & 0.032 & 29.908 & \\
\hline & Quality management 8 & 0.902 & - & Fixed & \\
\hline \multirow{10}{*}{$\begin{array}{l}\text { Competitive } \\
\text { intelligence } \\
\text { activities }\end{array}$} & Competitive intelligence 1 & 0.800 & 0.046 & 19.512 & \multirow{10}{*}{0.837} \\
\hline & Competitive intelligence 2 & 0.839 & 0.045 & 20.951 & \\
\hline & Competitive intelligence 3 & 0.824 & 0.047 & 20.442 & \\
\hline & Competitive intelligence 4 & 0.813 & 0.045 & 20.018 & \\
\hline & Competitive intelligence 5 & 0.636 & 0.051 & 14.204 & \\
\hline & Competitive intelligence 6 & 0.647 & 0.046 & 14.536 & \\
\hline & Competitive intelligence 7 & 0.635 & 0.047 & 14.192 & \\
\hline & Competitive intelligence 8 & 0.850 & 0.045 & 21.378 & \\
\hline & Competitive intelligence 9 & 0.842 & 0.037 & 27.103 & \\
\hline & Competitive intelligence 10 & 0.830 & - & Fixed & \\
\hline \multirow{11}{*}{$\begin{array}{l}\text { Technology } \\
\text { commercialization } \\
\text { capabilities }\end{array}$} & Technology commercialization 1 & 0.870 & - & Fixed & \multirow{11}{*}{0.846} \\
\hline & Technology commercialization 2 & 0.885 & 0.040 & 25.693 & \\
\hline & Technology commercialization 3 & 0.881 & 0.040 & 25.381 & \\
\hline & Technology commercialization 4 & 0.888 & 0.038 & 25.842 & \\
\hline & Technology commercialization 5 & 0.865 & 0.040 & 24.500 & \\
\hline & Technology commercialization 6 & 0.856 & 0.043 & 23.986 & \\
\hline & Technology commercialization 7 & 0.864 & 0.042 & 24.434 & \\
\hline & Technology commercialization 8 & 0.860 & 0.040 & 24.239 & \\
\hline & Technology commercialization 9 & 0.830 & 0.042 & 22.621 & \\
\hline & Technology commercialization 10 & 0.863 & 0.041 & 24.367 & \\
\hline & Technology commercialization 11 & 0.857 & 0.042 & 24.031 & \\
\hline \multirow{8}{*}{$\begin{array}{c}\text { Sustainable } \\
\text { competitive } \\
\text { advantage }\end{array}$} & Competitive advantage 1 & 0.809 & - & Fixed & \multirow{8}{*}{0.780} \\
\hline & Competitive advantage 2 & 0.828 & 0.052 & 19.653 & \\
\hline & Competitive advantage 3 & 0.831 & 0.053 & 19.761 & \\
\hline & Competitive advantage 4 & 0.856 & 0.052 & 20.660 & \\
\hline & Competitive advantage 5 & 0.824 & 0.054 & 19.545 & \\
\hline & Competitive advantage 6 & 0.803 & 0.062 & 18.843 & \\
\hline & Competitive advantage 7 & 0.799 & 0.062 & 18.707 & \\
\hline & Competitive advantage 8 & 0.845 & 0.058 & 18.495 & \\
\hline
\end{tabular}


Table 5. Cont.

\begin{tabular}{|c|c|c|c|c|c|}
\hline Variable & Measurement Item & Standardization Factor & S.E. & C.R. & CCR \\
\hline \multirow{8}{*}{$\begin{array}{c}\text { Business } \\
\text { performance }\end{array}$} & Business performance 1 & 0.875 & - & Fixed & \multirow{8}{*}{0.844} \\
\hline & Business performance 2 & 0.817 & 0.043 & 22.076 & \\
\hline & Business performance 3 & 0.826 & 0.045 & 22.444 & \\
\hline & Business performance 4 & 0.880 & 0.042 & 25.407 & \\
\hline & Business performance 5 & 0.864 & 0.040 & 24.464 & \\
\hline & Business performance 6 & 0.828 & 0.042 & 22.582 & \\
\hline & Business performance 7 & 0.866 & 0.041 & 24.633 & \\
\hline & Business performance 8 & 0.885 & 0.040 & 25.832 & \\
\hline
\end{tabular}

Note: $\chi^{2}=3384.072, \mathrm{df}=1240, p$-value $=0.000, \chi^{2} / \mathrm{df}=2.729, \mathrm{NFI}=0.868, \mathrm{CFI}=0.912, \mathrm{RMSEA}=0.065$.

\subsection{Correlation Analysis}

Table 6 shows the correlation analysis for this study. The correlation analysis showed significant correlation between knowledge management, quality management, competitive intelligence, technology commercialization capabilities, sustainable competitive advantage, and business performance at a level of $p=0.01$.

Table 6. Correlation analysis.

\begin{tabular}{|c|c|c|c|c|c|c|c|}
\hline \multicolumn{2}{|l|}{ Variable } & \multirow{2}{*}{$\begin{array}{c}01 \\
1\end{array}$} & \multirow{2}{*}{$\begin{array}{c}02 \\
-\end{array}$} & \multirow{2}{*}{$\begin{array}{c}03 \\
-\end{array}$} & \multirow{2}{*}{$\begin{array}{c}04 \\
-\end{array}$} & \multirow{2}{*}{$\begin{array}{c}05 \\
-\end{array}$} & \multirow{2}{*}{$\begin{array}{c}06 \\
-\end{array}$} \\
\hline Knowledge management & 01 & & & & & & \\
\hline Quality management & 02 & $0.801^{* *}$ & 1 & - & - & - & - \\
\hline Competitive intelligence & 03 & $0.834^{* *}$ & $0.832 * *$ & 1 & - & - & - \\
\hline $\begin{array}{c}\text { Technology } \\
\text { commercialization }\end{array}$ & 04 & $0.814^{* *}$ & $0.830 * *$ & $0.850 * *$ & 1 & - & - \\
\hline Competitive advantage & 05 & $0.794^{* *}$ & $0.849^{* *}$ & $0.820 * *$ & $0.838^{* *}$ & 1 & - \\
\hline Business performance & 06 & $0.768^{* *}$ & $0.790 * *$ & $0.757^{* *}$ & $0.741^{* *}$ & $0.791 * *$ & 1 \\
\hline Mean & & 7.635 & 7.430 & 7.725 & 7.528 & 7.383 & 7.450 \\
\hline Standard Deviation & & 1.776 & 1.918 & 1.576 & 1.818 & 1.854 & 1.758 \\
\hline
\end{tabular}

\subsection{Structural Equation Model Analysis}

We tested the hypotheses using structural equation model analysis; the results are as follows. First, quality management activities and competitive intelligence activities showed a statistically significant positive $(+)$ effect on technology commercialization capabilities. However, knowledge management activities did not show a statistically significant effect on technology commercialization capabilities. Second, quality management, competitive intelligence, and technology commercialization capabilities showed a statistically significant positive (+) effect on sustainable competitive advantage while knowledge management activities did not have a statistically significant effect on sustainable competitive advantage. Third, sustainable competitive advantage showed a statistically significant positive (+) effect on business performance while knowledge management, quality management, and competitive intelligence activities and technology commercialization capabilities did not have a statistically significant effect on business performance. Table 7 summarizes the results of the study. 
Table 7. Structural equation model analysis.

\begin{tabular}{|c|c|c|c|c|c|c|c|c|}
\hline $\begin{array}{c}\text { Result } \\
\text { Variables }\end{array}$ & & ath & & $\begin{array}{l}\text { Path } \\
\text { Coefficient }\end{array}$ & $t$ & $p$ & Hypothesis & $\begin{array}{l}\text { Supported/Not } \\
\text { Supported }\end{array}$ \\
\hline \multirow{3}{*}{$\begin{array}{l}\text { Technology } \\
\text { commercialization }\end{array}$} & Knowledge management & $\rightarrow$ & $\begin{array}{c}\text { Technology } \\
\text { commercialization }\end{array}$ & -0.039 & -0.280 & 0.779 & Hypothesis 1 & Not supported \\
\hline & Quality management & $\rightarrow$ & $\begin{array}{c}\text { Technology } \\
\text { commercialization }\end{array}$ & 0.345 & $2.843^{* *}$ & 0.004 & Hypothesis 2 & Supported \\
\hline & Competitive intelligence & $\rightarrow$ & $\begin{array}{c}\text { Technology } \\
\text { commercialization }\end{array}$ & 0.631 & $8.676^{* *}$ & 0.000 & Hypothesis 3 & Supported \\
\hline \multirow{4}{*}{$\begin{array}{l}\text { Competitive } \\
\text { advantage }\end{array}$} & Knowledge management & $\rightarrow$ & $\begin{array}{l}\text { Competitive } \\
\text { advantage }\end{array}$ & -0.277 & -1.900 & 0.057 & Hypothesis 4 & Not supported \\
\hline & Quality management & $\rightarrow$ & $\begin{array}{l}\text { Competitive } \\
\text { advantage }\end{array}$ & 0.591 & $4.479 * *$ & 0.000 & Hypothesis 5 & Supported \\
\hline & Competitive intelligence & $\rightarrow$ & $\begin{array}{l}\text { Competitive } \\
\text { advantage }\end{array}$ & 0.320 & $3.657^{* *}$ & 0.000 & Hypothesis 6 & Supported \\
\hline & $\begin{array}{c}\text { Technology } \\
\text { commercialization }\end{array}$ & $\rightarrow$ & $\begin{array}{l}\text { Competitive } \\
\text { advantage }\end{array}$ & 0.325 & $4.610^{* *}$ & 0.000 & Hypothesis 7 & Supported \\
\hline \multirow{5}{*}{$\begin{array}{l}\text { Business } \\
\text { performance }\end{array}$} & Knowledge management & $\rightarrow$ & Business performance & 0.320 & 1.831 & 0.067 & Hypothesis 8 & Not supported \\
\hline & Quality management & $\rightarrow$ & Business performance & 0.079 & 0.469 & 0.639 & Hypothesis 9 & Not supported \\
\hline & Competitive intelligence & $\rightarrow$ & Business performance & 0.085 & 0.784 & 0.433 & Hypothesis 10 & Not supported \\
\hline & $\begin{array}{c}\text { Technology } \\
\text { commercialization }\end{array}$ & $\rightarrow$ & Business performance & -0.081 & -0.945 & 0.345 & Hypothesis 11 & Not supported \\
\hline & Competitive advantage & $\rightarrow$ & Business performance & 0.484 & $4.862 * *$ & 0.000 & Hypothesis 12 & Supported \\
\hline \multicolumn{9}{|c|}{$\begin{array}{l}\text { SMC (Squared Multiple Correlations) }\left(\mathrm{R}^{2}\right) \\
\text { Technology commercialization: } 0.830(83.0 \%), \text { Com } \\
\chi^{2}=3410.501(\mathrm{df}=1243, p=0.000), \chi^{2} / \mathrm{df}=2.744 \\
\text { NFI }=0.867, \mathrm{CFI}=0.911, \text { RMSEA }=0.065\end{array}$} \\
\hline
\end{tabular}

Note: ${ }^{*} p<0.05,{ }^{* *} p<0.01$.

\section{Conclusions}

\subsection{Summary of the Research}

This study investigated the effects of sustainable management activities (knowledge management activities, quality management activities, and competitive intelligence activities) on technology commercialization capabilities, sustainable competitive advantage, and business performance. In addition, this study examined the effects of technology commercialization capabilities on sustainable competitive advantage and business performance. We also examined the effects of sustainable competitive advantage on business performance. We surveyed global firms for a total of 30 days from 1 October 2018 to 30 October 2018. We confined the survey's scope to members of the organizations at the level of team manager (or executives) or higher who were working in the R\&D department. We surveyed a total of 409 firms: 159 in Korea, 100 in the United States, 100 in the United Kingdom, and 50 companies in South Africa. Based on the valid data collected on 409 firms, we performed a structural equation model analysis; the results are summarized as follows.

(1) Knowledge management activities did not have a statistically significant effect on technology commercialization capabilities. These findings did not support the results of Moorthy and Polley [64], SubbaNarasimha et al. [110], and Zheng et al. [109]. Thus, knowledge management-based R\&D essentially helps the firm choose the correct path among uncertain and novel options [64]. However, because the firm's technical knowledge broadens as multiple directions of $R \& D$ are pursued by the organization's members, the firm may actually be at a disadvantage.

(2) Quality management activities showed a statistically significant positive (+) effect on technology commercialization capabilities. These findings supported the results of Gupta et al. [113] and Kannan and Tan [62]. Hence, quality-oriented activities lead to the continuous improvement of products (goods) and technological development. Moreover, firms perform scientific quality improvement activities to eventually improve process capabilities [62]. Improved process capabilities lead to the development of creative technology, which can generate future value for the firm [62]. 
(3) Competitive intelligence activities showed a statistically significant positive $(+)$ effect on technology commercialization capabilities. These findings supported the results of Aspinall [57] and Frishammar et al. [117]. In a dynamic environment, firms seize new opportunities and confront new threats as they focus on competitive intelligence activities [115]. Thus, while expanding their understanding of new changes in the environment through competitive intelligence activities, firms further enhance technology commercialization through continuous idea development and new product development $[57,117]$.

(4) Knowledge management activities did not have a statistically significant effect on sustainable competitive advantage. These findings did not support the research of Argote and Ingram [119] and Kearns and Lederer [63]. Thus, from the resource-based perspective that a firm's sustainable competitive advantage stems from its own knowledge resources, it is crucial to properly manage a firm's business resources on the global network [121]. However, knowledge is increasingly regarded as a source of competitive advantage for firms. This implies that the resulting knowledge resources may not act as a driving force to help secure other competitive advantages [122,123].

(5) Quality management activities showed a statistically significant positive (+) effect on sustainable competitive advantage. These findings supported the research of Lakhal [31] and Naveh and Marcus [126]. That is, various factors of quality management, such as price/cost and delivery reliability, affect aspects of competitive advantage [31]. In other words, quality management is a method to improve competitiveness and can help promote the organization's flexibility [125]. Because quality management is being used as firms' everyday activities and a catalyst for change, it can lead to competitive advantages in management and operations [31].

(6) Competitive intelligence activities showed a statistically significant positive (+) effect on sustainable competitive advantage. These findings supported the research of Bulger [58], Dishman and Calof [130], Heinrichs and Lim [127], and Hughes [128]. That is, competitive intelligence creates added value superior to new business development, market exploration, and strategic planning [130]. Previous literature has noted that competitive intelligence affects important decisions throughout the entire firm environment and is a key factor in securing and implementing competitive advantages [58].

(7) Technology commercialization capabilities showed a statistically significant positive (+) effect on sustainable competitive advantage. These findings supported the research of Cooper [131], Hwang and Sung [136], Kaleka and Morgan [61], and Li and Liu [132]. That is, technology commercialization is a vital success factor for survival in a rapidly changing market environment [131]. This helps ensure that the appropriate technology is available in the market and can be quickly developed and launched. This further indicates that technological commercialization can increase the firm's competitiveness as well as its product life cycles [61,132].

(8) Knowledge management activities did not have a statistically significant effect on business performance. These findings did not support the research of Barney [137], Seba and Rowley [65], Søderberg and Holden [139], and Zack et al. [140]. Thus, knowledge management activities such as knowledge acquisition, creation, sharing, and transfer play an important role in implementing superior management performance $[138,139]$. However, many global firms in the current era may face limitations in increasing business performance through profit, sales and market share if they possess only the necessary knowledge resources.

(9) Quality management activities did not have a statistically significant effect on business performance. These findings did not support the research of Curkovic et al. [149], Hendricks and Singhal [151], and Sankar [153]. That is, we infer that a considerable number of firms have introduced quality management in a state without a completely rooted quality management system. Consequently, it is likely that these firms did not achieve as high a level of business performance as expected. This indicates that there may be a number of areas that were not fully applied to product development, design, and production activities that the firm should 
identify and comply with the customers' and stakeholders' demands and the applicable laws and regulations.

(10) Competitive intelligence activities did not have a statistically significant effect on business performance. These results did not support the research of Fehringer et al. [156] and Hill and Jones [60]. Thus, when a firm possesses clear insight and understanding of its external environment, it can effectively make decisions and establish strategies, thereby achieving a high level of competitive advantage [155]. However, competitive intelligence activities did not lead to improvements in business performance. Hence, a firm must support insight and understanding of the external environment to successfully operate. However, this indicates that for numerous global firms in the current era, it may be insufficient for a direct influence on business performance.

(11) Technology commercialization capabilities did not have a statistically significant effect on business performance. These findings did not support the research of Chen [135], Cooper [131], Ho et al. [159], Lichtenthaler and Ernst [160], and Wolff and Pett [161]. That is, by introducing new technologies, technology commercialization capabilities enable firms to effectively respond to customer needs and environmental changes [25,158]. However, while technology commercialization capabilities can be applied to knowledge related to new technologies and market trends, thus enhancing firm competitiveness, it may be difficult to directly improve business performance using technology commercialization.

(12) Sustainable competitive advantage showed a statistically significant positive (+) effect on business performance. These findings supported the research of Li et al. [103] and Matsuno and Mentzer [164]. Possessing a competitive advantage typically implies that a firm provides at least either lower prices, higher quality, superior reliability, or faster delivery compared to competitors. These capabilities increase the overall performance of the organization [164] and can directly improve sales and profitability [165].

(13) Competitive intelligence activities is the factor that effects technology commercialization capabilities the most. Such a research outcome suggests that companies have to prepare for their future in a systematic manner. Nowadays, we are facing a variety of movements that could trigger a shake-up of the competitive environment such as the commoditization of technology, changes in social values, elimination of trade barriers, and environmental disasters. They can be disasters for those who did not prepare for significant changes, but opportunities for those who did. Companies make reaction plans when changes occur, but they all tend to lay out similar strategies. This is a somewhat natural phenomenon, given that the situations that companies face are similar. However, there are always some companies that would act differently from others and demonstrate distinctive technology commercialization capabilities. It is not possible to build distinctive technology commercialization capabilities in a short time, which all companies are striving to attain. It is possible only for companies that have attained competitive intelligence activities through persistent preparation.

(14) Quality management activities is the factor that affects sustainable competitive advantage the most. Such a research outcome highlights product quality as a factor of sustainable competitive advantage in today's management. Moreover, targets for quality perception need to be set and measures to attain such targets planned and executed in a strategic manner at the management level beyond internal control. Managers need to take the lead in promoting quality improvement to make and execute such quality strategies. To do so, managers themselves must understand the importance of quality and quality strategies. Just like most other strategic management, a company may effectively become one with a sustainable competitive advantage when it comes to quality strategy if it can, first, choose a correct strategic direction; second, properly allocate resources and attain internal capabilities for executing strategies; third, systematically execute strategic programs; and, fourth, have an attitude of working passionately and efficiently.

(15) A sustainable competitive advantage is the factor that affects business performance the most. This research outcome shows that companies with such an advantage have a high standard 
compared to other companies and outdo other companies in terms of profitability, market share, growth, and so on. Companies must learn and know ways to attain sustainable competitive advantage, in other words, ways to utilize core technology and resources strategically. To attain such advantage, companies need to correctly identify competitive elements that they have and utilize them effectively across the three stages of target, strategy, and infrastructure. However, companies do not have to have a competitive advantage across all competitive elements. In fact, it is impossible to maintain such advantage in all areas. Therefore, in this sense, companies need to first identify their distinctive elements and the relevant sustainable competitive advantage and determine a strategy to attain success accordingly.

\subsection{Research Implications}

We derived the following constructive implications from the results of this study. First, the importance of business organizations' strategic response capabilities lies in the visible contributions to sustainable competitive advantage and excellent profitability [172]. Therefore, in the business environment faced by the firm, $R \& D$ department managers (including marketing managers) must respond to uncertainties in products, manufacturing, and the market due to changes in the market and technology [173]. With increasing uncertainty, this implies that market response and perception capabilities are more important than ever when solidifying an organization's competitive advantage [172].

Second, among the tasks performed to gain insight into the uncertain social business environment, obtaining competitive information is of increasing importance [174]. Therefore, R\&D department managers (including marketing managers) must be able to quickly access competitive intelligence within the organization [175]. Quick access to competitive intelligence enables firms to apply it in times of crisis, thus creating competitive advantages.

Third, for a firm to uncover and acquire competitive insights, $R \& D$ department managers (including marketing managers) must search for evidence related to the problems and situations they face, perform accurate analyses, and devise informed countermeasures [176]. In fact, scholars suggest that realizing competitive advantage in addition to excellent business performance requires $R \& D$ department managers (including marketing managers) to analyze the uncertain environment, gain related insights, and contribute to the overall development of strategies [177].

Fourth, R\&D department managers (including marketing managers) must strategically use technology commercialization for internal operations as well as improving quality management, for example, by developing performance measurement indexes, management, and analysis [178]. To leverage technology commercialization, $R \& D$ department managers (including marketing managers) must acquire quality management and technology commercialization training indispensable for informed decision-making [179]. Furthermore, scholars suggest that firms should visualize their work processes through various marketing models to maintain competitiveness [180].

Fifth, sustainable management activity (knowledge management activities, quality management activities, and competitive intelligence activities) tools have been used to analyze the competitive environment and improve strategies and services [181]. This trend implies that the business environment leans more toward analysis as firms use competitive advantage tools, marketing decision models, and decision support technology [182]. Thus, the firm's enhanced management activities will help R\&D department managers (and marketing department managers) in segmentation marketing (a marketing technique that diversifies products, services, and sales methods according to the customer base's tendencies) efforts, reducing future uncertainty.

\subsection{Research Limitations and Future Research Directions}

Although this study provides numerous constructive implications, it contains the following limitations.

First, this study surveyed four countries, each on a different continent. However, it is somewhat difficult to generalize these global firms to each continent. Therefore, it is necessary to first examine 
global firms from a wider range of countries including China, Japan, Germany, and France and then examine the corresponding causal relationship.

Second, firms need strategic approaches to strengthen the capabilities of sustainable management activities (knowledge management, quality management, and competitive intelligence). Approximately $40 \%$ of the subjects in this study had a manufacturing-oriented business structure, which is a poor context for the creation of management activities. Global mid-sized and large firms typically form a structure that generates business performance based on their specific expertise and experience. Based on this, incentives are employed to strategically leverage management activities within the organization along with external knowledge. Therefore, this study has the limitation of an analysis of the causal relationships between technology commercialization capabilities, sustainable competitive advantage, and business performance according to the capabilities of the management activity subjects, regardless of firm size, sector, industry, or type of business.

Third, sustainable management activities (knowledge management, quality management, and competitive intelligence) require contracts to prevent the undesired spread of knowledge. Competitive knowledge workers can move to other companies at any time unless they own the firm. Furthermore, this tendency will accelerate in an individualistic society. Therefore, firms require strategies and incentives to retain these workers; future complex studies should reflect these various preceding factors through control variables.

Fourth, the validity of this study can be considered high as it surveyed team manager (or executive)-level employees or higher who were working in the R\&D departments of mid-size and large global firms to examine execution-centered knowledge management, quality management, and competitive intelligence activities. However, to conduct a multidimensional analysis, future research should divide this classification into top executives, mid-level managers, and relevant expert groups.

Author Contributions: All authors contributed to the content of this paper. All authors have read and agreed to the published version of the manuscript.

Funding: This research received no specific grant from any funding agency in the public, commercial, or not-for-profit sectors.

Conflicts of Interest: The authors declare that they have no competing interests.

\section{References}

1. Davenport, T.H.; Prusak, L. Working Knowledge: How Organizations Manage What They Know; Harvard Business School Press: Boston, MA, USA, 1998; pp. 1-75.

2. Liebowitz, J. Building Organizational Intelligence: A Knowledge Management Primer; CRC Press: Boca Raton, FL, USA, 1999; pp. 1-139.

3. Lim, K.K.; Ahmed, P.K.; Zairi, M. Managing for Quality Through Knowledge Management. Total Qual. Manag. 1999, 10, 615-621.

4. Drucker, P.F. The Coming of the New Organization. Harv. Bus. Rev. 1988, 66, 45-53.

5. Jen-Shan, K. Knowledge Economics in the Information Age. Ph.D. Thesis, Claremont Graduate University, Claremont, CA, USA, 2004; pp. 1-24.

6. Li-Yueh, C. An Examination of the Relationship Among Leadership Behaviors, Knowledge Sharing and Organization's Marketing Effectiveness in Professional Service Firms That Have Been Engaged in Strategic Alliance. Ph.D. Thesis, Nova South Eastern University, Davie, FL, USA, 2004; pp. 1-24.

7. Swart, J.; Kinnie, N. Sharing Knowledge in Knowledge-Intensive Firms. Hum. Resour. Manag. J. 2003, 13, 60-75.

8. Asif, M.; de Vries, H.J.; Ahmad, N. Knowledge Creation Through Quality Management. Total Qual. Manag. Bus. Excell. 2013, 24, 664-677.

9. Osayawe Ehigie, B.; McAndrew, E.B. Innovation, Diffusion and Adoption of Total Quality Management (TQM). Manag. Decis. 2005, 43, 925-940.

10. Flynn, B.B.; Schroeder, R.G.; Sakakibara, S. A Framework for Quality Management Research and an Associated Measurement Instrument. J. Oper. Manag. 1994, 11, 339-366. 
11. Owlia, M.S. A Framework for Quality Dimensions of Knowledge Management Systems. Total Qual. Manag. 2010, 21, 1215-1228.

12. Yang, C.L.; Wei, S.T. Modelling the Performance of CoP in Knowledge Management. Total Qual. Manag. 2010, 21, 1033-1045.

13. Sewdass, N. Proposing a competitive intelligence (CI) framework for Public Service departments to enhance service delivery. South Afr. J. Inf. Manag. 2012, 14, 1-13.

14. Chawinga, W.D.; Chipeta, G.T. A synergy of knowledge management and competitive intelligence: A key for competitive advantage in small and medium business enterprises. Bus. Inf. Rev. 2017, 34, 25-36.

15. Kahaner, L. Competitive Intelligence; Simon \& Schuster: New York, NY, USA, 1996.

16. Wright, S.; Bisson, C.; Duffy, A.P. Applying a Behavioural and Operational Diagnostic Typology of Competitive Intelligence Practice: Empirical Evidence from the SME Sector in Turkey. J. Strateg. Mark. 2012, 20, 19-33. [CrossRef]

17. Hitt, M.; Ireland, R.; Hoskisson, R. Annotated Textbook; Cengage Learning: New York, NY, USA, 2000; pp. 1-896.

18. Qiu, T. Scanning for Competitive Intelligence: A Managerial Perspective. Eur. J. Mark. 2008, 42, 814-835. [CrossRef]

19. M-Brain. Global Market Intelligence Survey 2015; M-Brain White Paper: Seoul, Korea, 2015.

20. Calof, J. Want a Good Return for Your CI dollar? Consider event intelligence. Compet. Intell. Mag. 2014, 17, 40-45.

21. Erickson, G.S.; Rothberg, H.N. Variation in Intellectual Capital Strategies Across Industries. In Proceedings of the 4th European Conference on Intellectual Capital, Helsinki, Finland, 23-24 April 2012; Academic Press International: Helsinki, Finland, 2012; pp. 180-188.

22. Tuan, L.T. Organisational Ambidexterity and Supply Chain Agility: The Mediating Role of External Knowledge Sharing and Moderating Role of Competitive Intelligence. Int. J. Logist. Res. Appl. 2016, 19, 583-603. [CrossRef]

23. Mohsin, A.A.; Halim, H.A.; Ahmad, N.H. Competitive Intelligence Among SMEs: Assessing the Role of Entrepreneurial Attitude Orientation on Innovation Performance; Springer: Gewerbestrasse, Switzerland, 2015; pp. 15-22.

24. Fiedler, M.; Welpe, I.M. Antecedents of Cooperative Commercialisation Strategies of Nanotechnology Firms. Res. Policy 2010, 39, 400-410. [CrossRef]

25. Gans, J.S.; Stern, S. The Product Market and the Market for "Ideas": Commercialization Strategies for Technology Entrepreneurs. Res. Policy 2003, 32, 333-350. [CrossRef]

26. Teece, D.J. Profiting from Technological Innovation: Implications for Integration, Collaboration, Licensing and Public Policy. Res. Policy 1986, 15, 285-305. [CrossRef]

27. Teece, D.J. Reflections on “Profiting from Innovation". Res. Policy 2006, 35, 1131-1146. [CrossRef]

28. Teece, D.J.; Pisano, G.; Shuen, A. Dynamic Capabilities and Strategic Management. Strateg. Manag. J. 1997, 18, 509-533. [CrossRef]

29. Jolly, V.K. Commercializing New Technologies: Getting from Mind to Market; Harvard Business School Press: Boston, MA, USA, 1997; pp. 1-432.

30. Mitchell, W.; Singh, K. Survival of Businesses Using Collaborative Relationships to Commercialize Complex Goods. Strateg. Manag. J. 1996, 17, 169-195. [CrossRef]

31. Lakhal, L. Impact of Quality on Competitive Advantage and Organizational Performance. J. Oper. Res. Soc. 2009, 60, 637-645. [CrossRef]

32. Pillai, K.G. Networks and Competitive Advantage: A Synthesis and Extension. J. Strateg. Mark. 2006, 14, 129-145. [CrossRef]

33. Calof, J.; Arcos, R.; Sewdass, N. Competitive Intelligence Practices of European Firms. Technol. Anal. Strateg. Manag. 2018, 30, 658-671. [CrossRef]

34. Porter, M.E. Competitive Strategy: Techniques for Analysing Industries and Competitors; Free Press: New York, NY, USA, 1980; pp. 1-398.

35. Barney, J. Firm Resources and Sustained Competitive Advantage. J. Manag. 1991, 17, 99-120. [CrossRef]

36. Teece, D.J. Economic Analysis and Strategic Management. Calif. Manag. Rev. 1984, 26, 87-110. [CrossRef]

37. Dyer, J.H.; Singh, H. The Relational View: Cooperative Strategy and Sources of Interorganizational Competitive Advantage. Acad. Manag. Rev. 1998, 23, 660-679. [CrossRef] 
38. Gatignon, H.; Xuereb, J.M. Strategic Orientation of the Firm and New Product Performance. J. Mark. Res. 1997, 34, 77-90. [CrossRef]

39. Hitt, M.; Ireland, R.; Hoskisson, R. Strategic Management: Concepts and Cases: Competitiveness and Globalization, 12th ed.; Cengage Learning: New York, NY, USA, 2016; pp. 1-896.

40. Sinkovics, R.R.; Roath, A.S. Strategic orientation, capabilities, and performance in manufacturer-3PL relationships. J. Bus. Log. 2004, 25, 43-64. [CrossRef]

41. Taghian, M.; Shaw, R.N. Market Fit and Business Performance: An Empirical Investigation. J. Strateg. Mark. 2010, 18, 395-415. [CrossRef]

42. Baskerville, R.; Dulipovici, A. The Theoretical Foundations of Knowledge Management. Knowl. Manag. Res. Pract. 2006, 4, 83-105. [CrossRef]

43. Barouch, G.; Ponsignon, F. The Epistemological Basis for Quality Management. Total Qual. Manag. Bus. Excell. 2016, 27, 1-19.

44. Trong Tuan, L. Organizational Social Capital as a Moderator for the Effect of Entrepreneurial Orientation on Competitive Intelligence. J. Strateg. Mark. 2017, 25, 301-315.

45. Pecotich, A.; Purdie, F.J.; Hattie, J. An Evaluation of Typologies of Marketplace Strategic Actions: The Structure of Australian Top Management Perceptions. Eur. J. Mark. 2003, 37, 498-529.

46. Powers, T.L.; Hahn, W. Critical Competitive Methods, Generic Strategies, and Firm Performance. Int. J. Bank Mark. 2004, 22, 43-64.

47. Pelham, A.M. Market Orientation and Other Potential Influences on Performance in Small and Medium-Sized Manufacturing Firms. J. Small Bus. Manag. 2000, 38, 48-67.

48. Pelham, A.M.; Wilson, D.T. A Longitudinal Study of the Impact of Market Structure, Firm Structure, Strategy, and Market Orientation Culture on Dimensions of Small-Firm Performance. J. Acad. Mark. Sci. 1995, 24, 27-43.

49. Narver, J.C.; Slater, S.F. The Effect of a Market Orientation on Business Profitability. J. Mark. 1990, 54, $20-35$.

50. Hill, S. The Tragedy of Technology: Human Liberation Versus Domination in the Late Twentieth Century; Pluto Press: London, UK, 1988; pp. 357-360.

51. Chang, Y.Y.; Mellahi, K.; Wilkinson, A. Control of Subsidiaries of MNCs from Emerging Economies in Developed Countries: The Case of Taiwanese MNCs in the UK. Int. J. Hum. Resour. Manag. 2009, 20, 75-95.

52. Storey, D.J. Exploring the Link, Among Small Firms, Between Management Training and Firm Performance: A Comparison Between the UK and Other OECD Countries. Int. J. Hum. Resour. Manag. 2004, 15, 112-130.

53. Giuliani, E.; Gorgoni, S.; Günther, C.; Rabellotti, R. Emerging Versus Advanced Country MNEs Investing in Europe: A Typology of Subsidiary Global-Local Connections. Int. Bus. Rev. 2014, 23, 680-691.

54. Hotho, J.J.; Lyles, M.A.; Easterby-Smith, M. The Mutual Impact of Global Strategy and Organizational Learning: Current Themes and Future Directions. Glob. Strategy J. 2015, 5, 85-112. [CrossRef]

55. Rush, H.; Bessant, J.; Hobday, M. Assessing the Technological Capabilities of Firms: Developing a Policy Tool. R D Manag. 2007, 37, 221-236. [CrossRef]

56. Spencer, J.W.; Gómez, C. The Relationship Among National Institutional Structures, Economic Factors, and Domestic Entrepreneurial Activity: A Multicountry Study. J. Bus. Res. 2004, 57, 1098-1107. [CrossRef]

57. Aspinall, Y. Competitive Intelligence in the Biopharmaceutical Industry: The Key Elements. Bus. Inf. Rev. 2011, 28, 101-104. [CrossRef]

58. Bulger, N.J. The Evolving Role of Intelligence: Migrating from Traditional Competitive Intelligence to Integrated Intelligence. Int. J. Intell. Sec. Public Aff. 2016, 18, 57-84. [CrossRef]

59. Hendricks, K.B.; Singhal, V.R. The Long-Run Stock Price Performance of Firms with Effective TQM Programs. Manag. Sci. 2001, 47, 359-368. [CrossRef]

60. Hill, C.; Jones, G. Essentials of Strategic Management. SOUTH-WESTERN, 3rd ed.; Cengage Learning: Mason, $\mathrm{OH}, \mathrm{USA}, 2011$; pp. 1-421.

61. Kaleka, A.; Morgan, N.A. Which Competitive Advantage (s)? Competitive Advantage-Market Performance Relationships in International Markets. J. Int. Mark. 2017, 25, 25-49. [CrossRef]

62. Kannan, V.R.; Tan, K.C. Just in Time, Total Quality Management, and Supply Chain Management: Understanding Their Linkages and Impact on Business Performance. Omega 2005, 33, 153-162. [CrossRef]

63. Kearns, G.S.; Lederer, A.L. A Resource-Based View of Strategic IT Alignment: How Knowledge Sharing Creates Competitive Advantage. Decis. Sci. 2003, 34, 1-29. [CrossRef] 
64. Moorthy, S.; Polley, D.E. Technological Knowledge Breadth and Depth: Performance Impacts. J. Knowl. Manag. 2010, 14, 359-377. [CrossRef]

65. Seba, I.; Rowley, J. Knowledge Management in UK Police Forces. J. Knowl. Manag. 2010, 14, 611-626. [CrossRef]

66. Choi, J.S.; Kwak, Y.M.; Choe, C. Corporate Social Responsibility and Corporate Financial Performance: Evidence from Korea. Aust. J. Manag. 2010, 35, 291-311. [CrossRef]

67. Kim, K.; Choi, Y.; Choi, C.Y.; Kim, H.J. The Role of Intermediaries on Technological Risk Management and Business Development Performance in Korea. Technol. Forecast. Soc. Change 2010, 77, 870-880. [CrossRef]

68. Lee, D.S.; Chung, L.C. A Study on the Effect of Technological Innovation Capability and Technology Commercialization Capability on Business Performance in SMEs of Korea. Asian Pac. J. Small Bus. 2010, 32, 65-87.

69. Rhee, J.; Park, T.; Lee, D.H. Drivers of Innovativeness and Performance for Innovative SMEs in South Korea: Mediation of Learning Orientation. Technovation 2010, 30, 65-75. [CrossRef]

70. Huang, T.P. Comparing Motivating Work Characteristics, Job Satisfaction, and Turnover Intention of Knowledge Workers and Blue-Collar Workers, and Testing a Structural Model of the Variables' Relationships in China and Japan. Int. J. Hum. Resour. Manag. 2011, 22, 924-944. [CrossRef]

71. Rao, J.; Yu, Y.; Cao, Y. The Effect That R\&D Has on Company Performance: Comparative Analysis Based on Listed Companies of Technique Intensive Industry in China and Japan. Int. J. Educ. Res. 2013, 1, 1-8.

72. Haeussler, C.; Colyvas, J.A. Breaking the Ivory Tower: Academic Entrepreneurship in the Life Sciences in UK and Germany. Res. Policy 2011, 40, 41-54. [CrossRef]

73. Elkington, J.; Rowlands, I.H. Cannibals with Forks: The Triple Bottom Line of 21st Century Business. Altern J. $1999,25,42-43$.

74. Stead, J.G.; Stead, W.E. Building Spiritual Capabilities to Sustain Sustainability-Based Competitive Advantages. J. Manag. Spirituality Relig. 2014, 11, 143-158. [CrossRef]

75. Schaltegger, S.; Freund, F.L.; Hansen, E.G. Business Cases for Sustainability: The Role of Business Model Innovation for Corporate Sustainability. Int. J. Innov. Sustain. Dev. 2012, 6, 95-119. [CrossRef]

76. Wagner, M. The Role of Corporate Sustainability Performance for Economic Performance: A Firm-Level Analysis of Moderation Effects. Ecol. Econ. 2010, 69, 1553-1560. [CrossRef]

77. Chawla, D.; Joshi, H. Knowledge Management Practices in Indian Industries: A Comparative Study. J. Knowl. Manag. 2010, 14, 708-725. [CrossRef]

78. Darroch, J. Developing a Measure of Knowledge Management Behaviors and Practices. J. Knowl. Manag. 2003, 7, 41-54. [CrossRef]

79. Kiessling, T.S.; Richey, R.G.; Meng, J.; Dabic, M. Exploring Knowledge Management to Organizational Performance Outcomes in a Transitional Economy. J. World Bus. 2009, 44, 421-433. [CrossRef]

80. Bhatti, K.K.; Qureshi, T.M. Impact of Employee Participation on Job Satisfaction, Employee Commitment and Employee Productivity. Int. Rev. Bus. Res. Pap. 2007, 3, 54-68.

81. Dahlgaard-Park, S.M. The Quality Movement: Where Are You Going? Total Qual. Manag. Bus. Excell. 2011, 22, 493-516. [CrossRef]

82. Rungtusanatham, M.; Ogden, J.A.; Wu, B. Advancing Theory Development in Total Quality Management: A “Deming Management Method" Perspective. Int. J. Oper. Prod. Manag. 2003, 23, 918-936. [CrossRef]

83. Deming, W.E. The New Economics for Industry, Government, Education; MIT Press Center for Advanced Engineering Study: Cambridge, MA, USA, 1993; pp. 1-266.

84. Anderson, J.C.; Rungtusanatham, M.; Schroeder, R.G. A Theory of QM Underlying the Deming Management Method. Acad. Manag. Rev. 1994, 19, 472-509. [CrossRef]

85. Hillmer, S.; Karney, D. Towards Understanding the Foundations of Deming's Theory of Management. J. Qual. Manag. 1997, 2, 171-189. [CrossRef]

86. Hillmer, S.; Karney, D. In Support of the Assumptions at the Foundation of Deming's Management Theory. J. Qual. Manag. 2001, 6, 371-400. [CrossRef]

87. Sousa, R.; Voss, C.A. Quality Management re-Visited: A Reflective Review and Agenda for Future Research. J. Oper. Manag. 2002, 20, 91-109. [CrossRef]

88. Vedder, R.G.; Vanecek, M.T.; Guynes, C.S.; Cappel, J.J. CEO and CIO Perspectives on Competitive Intelligence. Commun. ACM 1999, 42, 108-116. [CrossRef] 
89. Du Toit, A.S.A. Comparative Study of Competitive Intelligence Practices Between Two Retail Banks in Brazil and South Africa. J. Intell. Stud. Bus. 2013, 3, 30-39. [CrossRef]

90. Du Plessis, T.; Gulwa, M. Developing a Competitive Intelligence Strategy Framework Supporting the Competitive Intelligence Needs of a Financial Institution's Decision Makers. S. Afr. J. Inf. Manag. 2016, 18, 1-8. [CrossRef]

91. Jenster, P.; Søilen, K.S. The Relationship Between Strategic Planning and Company Performance: A Chinese Perspective. J. Intell. Stud. Bus. 2013, 3, 15-30.

92. Amara, Y.; Solberg Søilen, K.; Vriens, D.J. Using the SSAV Model to Evaluate Business Intelligence Software. J. Intell. Stud. Bus. 2012, 2, 29-40. [CrossRef]

93. Vriens, D.J.; Solberg Søilen, K. Disruptive Intelligence: How to Gather Information to Deal with Disruptive Innovations. J. Intell. Stud. Bus. 2014, 4, 63-78. [CrossRef]

94. Nevens, T.M.; Summe, G.L.; Uttal, B. Commercializing Technology: What the Best Companies Do? Harv. Bus. Rev. 1990, 68, 154-163. [CrossRef]

95. Aarikka-Stenroos, L.; Sandberg, B. From New-Product Development to Commercialization Through Networks. J. Bus. Res. 2012, 65, 198-206. [CrossRef]

96. Stevens, G.; Burley, J.; Divine, R. Creativity Business Discipline = Higher Profits Faster from New Product Development. J. Prod. Innov. Manag. 1999, 16, 455-468.

97. Zahra, S.A.; Nielsen, A.P. Sources of Capabilities, Integration and Technology Commercialization. Strateg. Manag. J. 2002, 23, 377-398. [CrossRef]

98. Li, Y.; Li, L.; Liu, Y.; Wang, L. Linking Management Control System with Product Development and Process Decisions to Cope with Environment Complexity. Int. J. Prod. Res. 2005, 43, 2577-2591. [CrossRef]

99. Song, X.M.; Di Benedetto, C.A.; Song, L.Z. Pioneering Advantage in New Service Development: A Multi-Country Study of Managerial Perceptions. J. Prod. Innov. Manag. 2000, 17, 378-392. [CrossRef]

100. Porter, M.E. Competitive Advantage: Creating and Sustaining Superior Performance; Free Press: New York, NY, USA, 1985; pp. 1-14.

101. Tracey, M.; Vonderembse, M.A.; Lim, J.S. Manufacturing Technology and Strategy Formulation: Keys to Enhancing Competitiveness and Improving Performance. J. Oper. Manag. 1999, 17, 411-428. [CrossRef]

102. Koufteros, X.A.; Vonderembse, M.A.; Doll, W.J. Competitive Capabilities: Measurement and Relationships; Decision Science Institute: Atlanta, GA, USA, 1997; pp. 1067-1068.

103. Li, S.; Ragu-Nathan, B.; Ragu-Nathan, T.S.; Subba Rao, S.S. The Impact of Supply Chain Management Practices on Competitive Advantage and Organizational Performance. Omega 2006, 34, 107-124. [CrossRef]

104. Stock, G.N.; Greis, N.P.; Kasarda, J.D. Enterprise Logistics and Supply Chain Structure: The Role of Fit. J. Oper. Manag. 2000, 18, 531-547.

105. Powell, T.C. Organizational Alignment as Competitive Advantage. Strateg. Manag. J. 1992, 13, $119-134$. [CrossRef]

106. Hult, G.T.M.; Hurley, R.F.; Knight, G.A. Innovativeness: Its Antecedents and Impact on Business Performance. Ind. Mark. Manag. 2004, 33, 429-438.

107. Chen, M.C.; Cheng, S.J.; Hwang, Y. An Empirical Investigation of the Relationship Between Intellectual Capital and Firms' Market Value and Financial Performance. J. Intellect. Cap. 2005, 6, 159-176. [CrossRef]

108. Stanwick, P.A.; Stanwick, S.D. The Relationship Between Corporate Social Performance, and Organizational Size, Financial Performance, and Environmental Performance: An Empirical Examination. J. Bus. Ethics 1998, 17, 195-204. [CrossRef]

109. Zheng, W.; Yang, B.; McLean, G.N. Linking Organizational Culture, Structure, Strategy, and Organizational Effectiveness: Mediating Role of Knowledge Management. J. Bus. Res. 2010, 63, 763-771. [CrossRef]

110. SubbaNarasimha, P.N.; Ahmad, S.; Mallya, S.N. Technological Knowledge and Firm Performance of Pharmaceutical Firms. J. Intellect. Cap. 2003, 4, 20-33. [CrossRef]

111. Prajogo, D.I.; Sohal, A.S. The Integration of TQM and Technology/R\&D Management in Determining Quality and Innovation Performance. Omega 2006, 34, 296-312.

112. Baird, K.; Jia Hu, K.; Reeve, R. The Relationships Between Organizational Culture, Total Quality Management Practices and Operational Performance. Int. J. Oper. Prod. Manag. 2011, 31, 789-814. [CrossRef]

113. Gupta, A.; McDaniel, J.C.; Kanthi Herath, S. Quality Management in Service Firms: Sustaining Structures of Total Quality Service. Managing Service Quality. An. Int. J. 2005, 15, 389-402. 
114. Bhatt, G.; Emdad, A.; Roberts, N.; Grover, V. Building and Leveraging Information in Dynamic Environments: The Role of IT Infrastructure Flexibility as Enabler of Organizational Responsiveness and Competitive Advantage. Inf. Manag. 2010, 47, 341-349. [CrossRef]

115. Nasri, W. Competitive Intelligence in Tunisian Companies. J. Enterp. Inf. Manag. 2011, 24, 53-67. [CrossRef]

116. Camisón, C.; Forés, B. Knowledge Absorptive Capacity: New Insights for Its Conceptualization and Measurement. J. Bus. Res. 2010, 63, 707-715. [CrossRef]

117. Frishammar, J.; Lichtenthaler, U.; Rundquist, J. Identifying Technology Commercialization Opportunities: The Importance of Integrating Product Development Knowledge. J. Prod. Innov. Manag. 2012, 29, 573-589. [CrossRef]

118. Spender, J.-C.; Grant, R.M. Knowledge and the Firm: Overview. Strateg. Manag. J. 1996, 17, 5-9. [CrossRef]

119. Argote, L.; Ingram, P. Knowledge Transfer: A Basis for Competitive Advantage in Firms. Organ. Behav. Hum. Decis. Process. 2000, 82, 150-169. [CrossRef]

120. Chuang, S.H. A Resource-Based Perspective on Knowledge Management Capability and Competitive Advantage: An Empirical Investigation. Expert Syst. Appl. 2004, 27, 459-465. [CrossRef]

121. Peteraf, M.A. The Cornerstones of Competitive Advantage: A Resource-Based View. Strateg. Manag. J. 1993, 14, 179-191. [CrossRef]

122. Oliver, C. Sustainable Competitive Advantage: Combining Institutional and Resource-Based Views. Strateg. Manag. J. 1997, 18, 697-713. [CrossRef]

123. Wright, P.M.; McMahan, G.C.; McWilliams, A. Human Resources and Sustained Competitive Advantage: A Resource-Based Perspective. Int. J. Hum. Resour. Manag. 1994, 5, 301-326. [CrossRef]

124. Powell, T.C. Total Quality Management as Competitive Advantage: A Review and Empirical Study. Strateg. Manag. J. 1995, 16, 15-37. [CrossRef]

125. Oakland, J.S. Total Quality Management: A Pictorial Guide for Managers; Butterworth-Heinemann: Oxford, UK, 1979; pp. 1-96.

126. Naveh, E.; Marcus, A. Achieving Competitive Advantage Through Implementing a Replicable Management Standard: Installing and Using ISO 9000 ISO 9000. J. Oper. Manag. 2005, 24, 1-26. [CrossRef]

127. Heinrichs, J.H.; Lim, J.S. Impact of Marketing Model Application and Competitive Intelligence Utilization on Strategic Response Capability. J. Strateg. Mark. 2008, 16, 91-110. [CrossRef]

128. Hughes, S. Competitive Intelligence as Competitive Advantage. J. Compet. Intell. Manag. 2005, 3, 3-18.

129. Wright, S.; Eid, E.R.; Fleisher, C.S. Competitive Intelligence in Practice: Empirical Evidence from the UK Retail Banking Sector. J. Mark. Manag. 2009, 25, 941-964. [CrossRef]

130. Dishman, P.L.; Calof, J.L. Competitive Intelligence: A Multiphasic Precedent to Marketing Strategy. Eur. J. Mark. 2008, 42, 766-785. [CrossRef]

131. Cooper, L.G. Strategic Marketing Planning for Radically New Products. J. Mark. 2000, 64, 1-16.

132. Li, D.Y.; Liu, J. Dynamic Capabilities, Environmental Dynamism, and Competitive Advantage: Evidence from China. J. Bus. Res. 2014, 67, 2793-2799. [CrossRef]

133. Yu, J.; Subramanian, N.; Ning, K.; Edwards, D. Product Delivery Service Provider Selection and Customer Satisfaction in the Era of Internet of Things: A Chinese e-Retailers' Perspective. Int. J. Prod. Econ. 2015, 159, 104-116. [CrossRef]

134. Sohn, S.Y.; Moon, T.H. Structural equation model for predicting technology commercialization success index (TCSI). Technol. Forecast. Soc. Change 2003, 70, 885-899. [CrossRef]

135. Chen, C.J. Technology Commercialization, Incubator and Venture Capital, and New Venture Performance. J. Bus. Res. 2009, 62, 93-103. [CrossRef]

136. Hwang, K.Y.; Sung, E.H. How Technology Innovation Capability and Technology Commercialization Competence Affect Competitive Advantage: An Evidence from Export Firms of Deadeok Innpolis. Int. Area Stud. Rev. 2015, 19, 365-387.

137. Barney, J. Gaining and Sustaining Competitive Advantage, 3rd ed.; Pearson Education: Upper Saddle River, NJ, USA, 2007; pp. 1-520.

138. Spender, J.-C. Making Knowledge the Basis of a Dynamic Theory of the Firm. Strateg. Manag. J. 1996, 17, $45-62$.

139. Søderberg, A.M.; Holden, N. Rethinking cross cultural management in a globalizing business world. Int. J. Cross Cult. Manag. 2002, 2, 103-121. [CrossRef] 
140. Zack, M.; McKeen, J.; Singh, S. Knowledge Management and Organizational Performance: An Exploratory Analysis. J. Knowl. Manag. 2009, 13, 392-409. [CrossRef]

141. Buzzell, R.D.; Wiersema, F.D. Modelling Changes in Market Share: A Cross-Sectional Analysis. Strateg. Manag. J. 1981, 2, 27-42. [CrossRef]

142. Jacobson, R.; Aaker, D.A. The Strategic Role of Product Quality. J. Mark. 1987, 51, 31-44. [CrossRef]

143. Mann, R.; Kehoe, D. An Evaluation of the Effects of Quality Improvement Activities on Business Performance. Int. J. Qual. Reliab. Manag. 1994, 11, 29-44. [CrossRef]

144. Wagner, H.M. Profit Wonders, Investment Blunders. Harv. Bus. Rev. 1984, 62, 121-135.

145. Larson, P.D.; Sinha, A. The TQM Impact: A Study of Quality Managers' Perceptions. Qual. Manag. J. 1995, 2, 53-66. [CrossRef]

146. Rayner, P.; Porter, L.J. BS5750/ISO 9000-the Experience of Small and Medium-Sized Firms. Int. J. Qual. Reliab. Manag. 1991, 8, 16-28. [CrossRef]

147. Voss, C.; Blackmon, K. Total Quality Management and ISO 9000: A European Study [Working Paper]; Center for Operations Management, London Business School: London, UK, 1994; pp. 1-10.

148. Adam, E.E., Jr. Alternative Quality Improvement Practices and Organization Performance. J. Oper. Manag. 1994, 12, 27-44. [CrossRef]

149. Curkovic, S.; Vickery, S.K.; Droge, C. Quality and Business Performance: An Empirical Study of First-Tier Automotive Suppliers. Qual. Manag. J. 1999, 6, 29-40. [CrossRef]

150. Forker, L.B.; Vickery, S.K.; Droge, C.L.M. The Contribution of Quality to Business Performance. Int. J. Oper. Prod. Manag. 1996, 16, 44-62. [CrossRef]

151. Hendricks, K.B.; Singhal, V.R. Quality Awards and the Market Value of the Firm: An Empirical Investigation. Manag. Sci. 1996, 42, 415-436. [CrossRef]

152. Maani, K.E.; Putterill, M.S.; Sluti, D.G. Empirical Analysis of Quality Improvement in Manufacturing. Int. J. Qual. Reliab. Manag. 1994, 11, 19-37. [CrossRef]

153. Sankar, M. Self-Assessment Using the Baldrige Criteria; AQSC Professional and Technical Development: Milwaukee, WI, USA, 1997; pp. 45-48.

154. Prajogo, D.I. The Strategic Fit Between Innovation Strategies and Business Environment in Delivering Business Performance. Int. J. Prod. Econ. 2016, 171, 241-249. [CrossRef]

155. Schilke, O. On the Contingent Value of Dynamic Capabilities for Competitive Advantage: The Nonlinear Moderating Effect of Environmental Dynamism. Strateg. Manag. J. 2014, 35, 179-203. [CrossRef]

156. Fehringer, D.; Hohhof, B.; Johnson, T. State of the Art: Competitive Intelligence; Competitive Intelligence Foundation: Washington, DC, USA, 2006; pp. 1-159.

157. Prescott, J.; Herring, J.; Panfely, P. Leveraging Information for Action: A Look into the Competitive and Business Intelligence Consortium Benchmarking Study. Comp. Int. Rev. 1998, 9, 4-12. [CrossRef]

158. Kasch, S.; Dowling, M. Commercialization Strategies of Young Biotechnology Firms: An Empirical Analysis of the US Industry. Res. Policy 2008, 37, 1765-1777. [CrossRef]

159. Ho, Y.C.; Fang, H.C.; Lin, J.F. Technological and Design Capabilities: Is Ambidexterity Possible? Manag. Decis. 2011, 49, 208-225. [CrossRef]

160. Lichtenthaler, U.; Ernst, H. External Technology Commercialization in Large Firms: Results of a Quantitative Benchmarking Study. R D Manag. 2007, 37, 383-397. [CrossRef]

161. Wolff, J.A.; Pett, T.L. Small-Firm Performance: Modeling the Role of Product and Process Improvements. J. Small Bus. Manag. 2006, 44, 268-284. [CrossRef]

162. Chiesa, V.; Frattini, F. Commercializing Technological Innovation: Learning from Failures in High-Tech Markets. J. Prod. Innov. Manag. 2011, 28, 437-454. [CrossRef]

163. Schilling, M.A. Strategic Management of Technological Innovation; McGraw-Hill: New York, NY, USA, 2005; pp. 1-336.

164. Matsuno, K.; Mentzer, J.T. The Effects of Strategy Type on the Market Orientation-Performance Relationship. J. Mark. 2000, 64, 1-16.

165. Moran, P. Structural vs. Relational Embeddedness: Social Capital and Managerial Performance. Strateg. Manag. J. 2005, 26, 1129-1151.

166. Seok, B.I.; Han, M.P.; Kim, J.H. Knowledge and Quality-Management Activities' Influences on Technology Communication and Innovation with African Foreign Investment Experience. J. Psychol. Afr. 2018, 28, 310-315. [CrossRef] 
167. Kim, K.S.; John, E.P.; Ravi, M. An Exploratory Comparative Study on Competitive Intelligence of Korean and American Companies. Int. Bus. Rev. 2006, 10, 153-170. [CrossRef]

168. Lee, K.O.; Park, H.S. The Influence of Small Firm CEO's Entrepreneurial Attributes in the Start-up Phase on DFCA and Business Performance: Focus on Mediating Effects of DFCA. Asia Pac. J. Bus. Ventur. Entrep. 2015, $10,69-82$.

169. Kim, J.H.; Jung, S.H. Study on CEO Characteristics for Management of Public Art Performance Centers. J. Open Innov. Technol. Mark. Complex. 2015, 1, 1-21.

170. Han, M.P.; Seok, B.I.; Kim, J.H. The Effects of 6 Personality Factors of CEO at Small and Medium-Sized Enterprises on the Performances in Business Management: Focusing on Learning and Growth. Asian Acad. Manag. J. 2017, 22, 97-128. [CrossRef]

171. Anderson, J.C.; Gerbing, D.W. Structural Equation Modeling in Practice: A Review and Recommended Two-Step Approach. Psychol. Bull. 1988, 103, 411-423.

172. Day, G.S. The Capabilities of Market-Driven Organizations. J. Mark. 1994, 58, 37-52.

173. Grewal, R.; Tansuhaj, P. Building Organizational Capabilities for Managing Economic Crisis: The Role of Market Orientation and Strategic Flexibility. J. Mark. 2001, 65, 67-80.

174. Souchon, A.L.; Cadogan, J.W.; Procter, D.B.; Dewsnap, B. Marketing Information Use and Organizational Performance: The Mediating Role of Responsiveness. J. Strateg. Mark. 2004, 12, 231-242. [CrossRef]

175. Benjamin, R.I.; Levinson, E. A Framework for Managing IT-Enabled Change. Sloan Manag. Rev. 1993, 34, $22-33$.

176. White, J.C.; Varadarajan, P.R.; Dacin, P.A. Market Situation Interpretation and Response: The Role of Cognitive Style, Organizational Culture, and Information Use. J. Mark. 2003, 67, 63-79. [CrossRef]

177. Morgan, R.E.; Thorpe, E.R.; McGuinness, T.; Thorpe, E.R. The Contribution of Marketing to Business Strategy Formation: A Perspective on Business Performance Gains. J. Strateg. Mark. 2000, 8, 341-362. [CrossRef]

178. Vorhies, D.W.; Morgan, N.A. A Configuration Theory Assessment of Marketing Organization Fit with Business Strategy and Its Relationship with Marketing Performance. J. Mark. 2003, 67, 100-115. [CrossRef]

179. Darr, E.D.; Argote, L.; Epple, D. The Acquisition, Transfer, and Depreciation of Knowledge in Service Organizations: Productivity in Franchises. Manag. Sci. 1995, 41, 1750-1762. [CrossRef]

180. Carrillo, J.E.; Gaimon, C. Improving Manufacturing Performance Through Process Change and Knowledge Creation. Manag. Sci. 2000, 46, 265-288. [CrossRef]

181. Peters, M.P.; Brush, C.G. Market Information Scanning Activities and Growth in New Ventures: A Comparison of Service and Manufacturing Businesses. J. Bus. Res. 1996, 36, 81-89. [CrossRef]

182. Bronnenberg, B.J.; Sismeiro, C. Using Multimarket Data to Predict Brand Performance in Markets for Which No or Poor Data Exist. J. Mark. Res. 2002, 39, 1-17. [CrossRef] 